\title{
AVAR KORI TELEPRÉSZLET CSANÁDPALOTA-ORSZÁGHATÁR LELŐHELYEN A 7. SZÁZADI TELEPEK KÉRDÉSE AZ ALFÖLDÖN
}

\author{
PÓPITY DÁNIEL*
}

\begin{abstract}
Taking the description of the Avar period settlement recently investigated at CsanádpalotaOrszághatár as his springboard, the author discusses various issues in the research of the early Avar settlements of the Hungarian Plain. Addressed in the study are the distinctive traits that can be of help in identifying the period's settlements in this region. The greatest difficulty in this field of research is the almost complete lack of wheel-turned ceramic wares and the uncertainties in the dating of hand-thrown pottery.
\end{abstract}

Keywords: Carpathian Basin, Hungarian Plain, early Avar period settlements, early Avar period grey ware, Tarnaméra type strap end

A szerző a közelmúltban feltárt Csanádpalota-országhatár avar kori teleprészlet bemutatásán keresztül az Alföld kora avar kori településeinek kérdéskörével foglalkozik. Keresi azokat a jellegzetességeket, amelyek segithetik a korszak településeinek azonositását az Alföldön. Nehézségeket okoz a korongolt kerámia csaknem teljes hiánya, valamint a korongolatlan kerámia keltezésének bizonytalansága.

Kulcsszavak: Kárpát-medence, Alföld, kora avar kori telepek, kora avar kori szürke kerámia, Tarnaméra-típusú szíjvég

A keleti sztyeppéről érkező és a Kárpátmedencében 567/568-ban megtelepedő avarság az európaitól eltérő, keleti típusú gazdasági modell megjelenését is jelentette az érintett régióban. Az avar nép viszonyát a tájhoz kezdetben a nomád életforma határozta meg. A tágas térségekhez szokott, nagy mobilitással rendelkező, elsősorban állattenyésztô életmódot folytató, pásztorkodó korai avar csoportok kezdetben nem rendelkeztek állandó szállással, noha a Kárpátmedencében egységes politikai alakulatot hoztak létre. ${ }^{1} \mathrm{Az}$ ideiglenes szállások sátrakból, jurták-

A kézirat érkezett: 2015. május 18.

* Pópity Dániel. Móra Ferenc Múzeum, 6720 Szeged, Roosevelt tér 1-3.; popitydani@gmail.com

1 BÓNA 1973, 83; LÓRINCZY 1998, 343-372. ból állhattak, amelyeknek nem maradt régészetileg megfogató nyoma. A letelepült életforma legkorábbi időszakában - ahogyan a kelet-európai példák mutatják - a nomád és félnomád avarok esetében is számolhatunk kerek, csak igen sekélyen a földbe mélyített ún. ,jurta alakú házak$\mathrm{kal}^{\prime \prime}{ }^{2}$ Ezekben tüzelőhely is lehetett. Jurta alakú avar kori ház eddig csak az alföldi területről ismert, a 8. századi kompolti avar kori településról. ${ }^{3}$

A betelepedők kezdetben döntóen állattartással foglalkoztak. Az újonnan meghódított terület

\footnotetext{
FODOR 2006, 220-222; ŠALKOVSKÝ 2011, 424-425.

3 TAKÁCS 2002, 280.
} 
azonban földrajzi adottságainál fogva csupán az egyszállású legeltetésre volt alkalmas. Ennek következtében a 7 . század elején a betelepülő avarok második-harmadik generációja már állandó településeken élhetett. ${ }^{4}$ Ma már egyre bizonyosabbnak túnik, hogy a legkorábbi állandó avar kori települések egy idóben jelentek meg az Alföldön és a Dunántúlon, a 7. század első harmadában. Az állandóan lakott települések melletti területen a földmúvelés is egyre jelentősebbé válhatott. ${ }^{5} \mathrm{~A}$ megtelepedés és a vele járó letelepült életmódra történő váltás valószínúleg a 7 . század végén lezárult. Ennek nyomán tanyaszerú szállások, falvak alakultak ki. A szilárd településhálózatot ma a temetókhöz képest jóval alacsonyabb számú korai telep jelzi. Jelen dolgozatban az alföldi avarok korai településeire vonatkozó információkat összegzem. A kora középkori teleprégészet e problémás területének kérdéséhez támpontként egy újonnan előkerült csanádpalotai településrészlet adatait is felhasználom. ${ }^{6}$

\section{A 7. századi telepek kutatásának kezdetei a Dunántúlon}

Az Alföld 7. századi településeinek vizsgálata előtt érdemes áttekinteni a hasonló korú dunántúli lelőhelyek kutatását. Az Alföld mint földrajzi értelemben vett nagytáj nem a Dunáig tart, hiszen a Mezőföld és a Dráva menti síkság átnyúlik a Dunántúlra. Jelen régészeti áttekintés vizsgálatának határát a Duna vonalában jelöli meg, mert ettól a vonaltól nyugatra már más kulturális hatások érvényesültek az avar korban. Mindezt jól mutatják a dunántúli avar kori telepek feltárásának tapasztalatai. Ezek az adatok viszont sok esetben hivatkozási alapot, egyfajta régészeti „etalont” jelentenek az Alföld korai telepeinek vizsgálata során is. ${ }^{7}$

Az első és alapvető jelentőségú munka ebben a témában Bóna István monográfiája Dunaújváros-Öreghegy avar kori településéról, amely új korszakot nyitott az avar kori települések kutatásában. ${ }^{8}$ A Dunaújvárosban napvilágra került és a korai megtelepedéshez köthető kerámia 80\%-a

4 BÓNA 1984, 329-330.

FODOR 2006, 25-29.

Készült a 104533. számú OTKA-pályázat keretében. Ezúton is köszönöm Takács Miklósnak és a téma alapötletét adó Vida Tivadarnak, hogy a cikk készítése során hasznos megjegyzéseikkel segítették és ösztönözték munkámat.

MADARAS 1986, 34, 44; FODOR 2012, 713, 7.

BÓNA 1973. szabad kézzel formált edény volt, 9\%-a pedig gyorskorongolt szürke díszkerámia. Utóbbit gyakran vízszintesen befésült fésûs, egyenes és hullámvonalköteggel díszítették. Alföldi jelentőségéről később még szó lesz. A leletek között elvétve feltúntek a korongolt fekete vagy sötétszürke színú edények töredékei is, amelyek a Dunántúlon, a Duna mentén a 7. századtól a 8. század közepéig voltak használatban. ${ }^{9}$ Bóna a telepet két korai fázisra osztotta, de a két fázis elkülönítésére kevés támpontot nevezett meg. Véleménye szerint a korai fázisban a kiöntőcsöves szürke korsók, a második fázisban a bikónikus orsógombok a gyakoribbak. A hullámvonaldíszes, szürke, gyorskorongolt kerámia, a sima és benyomkodott peremú, szabad kézzel formált edények mindkét periódusban megtalálhatóak. ${ }^{10}$

Bóna István munkája a korszak településeinek hiányára is ráirányította a figyelmet, és útmutatásul szolgált a további kutatások során. Az 1970-1980-as években a Dunántúl területén újabb és újabb korai, azaz 7. századiként meghatározott településnyomok váltak ismertté hasonló összetételú leletanyaggal. A teljesség igénye nélkül: Tatabánya-Alsógalla, ${ }^{11}$ Szekszárd-Bogyiszló, ${ }^{12}$ Kálóz-Nagyhörcsök. ${ }^{13}$ A telepek sorában mind méreteiben, mind a feltárt objektumok számát és leletgazdagságát tekintve kiemelkedő a Kiss Attila által Kölked-Feketekapun 1970 és 1999 között feltárt avar temető és település. ${ }^{14} \mathrm{Az}$ itt talált mécseseket, a késő antik jellegú kerámiát, a cserépbográcsokat és sütőharangokat, a település házait, valamint a telep pecsételt díszú kerámiaanyagában mutatkozó sajátosságokat, szabályosságokat Hajnal Zsuzsanna vizsgálta. ${ }^{15}$

Kiss Attila 1979-ben feltérképezte a Kárpátmedencében addig ismert 5-9. századi telepeket. Térképén a legfontosabb avar kori telepek is szerepeltek. ${ }^{16}$ 1981-ben Garam Éva a 8-9. századi tiszafüredi telepről szóló tanulmányában Kiss Attila térképét további avar telepekkel egészítette ki. Köztük öt, biztosan kora avar kori telep is szerepel: Dunaújváros, Kálóz-Nagyhörcsök, Kölked-Feketekapu, Szekszárd-Bogyiszló, Tatabánya-Alsógalla. ${ }^{17}$ Uwe Fiedler 1994-ben, a Kárpát-medence 7-10. századi telepeinek kérdéskörével foglalkozó vitacikkében Garam Éva emlí-

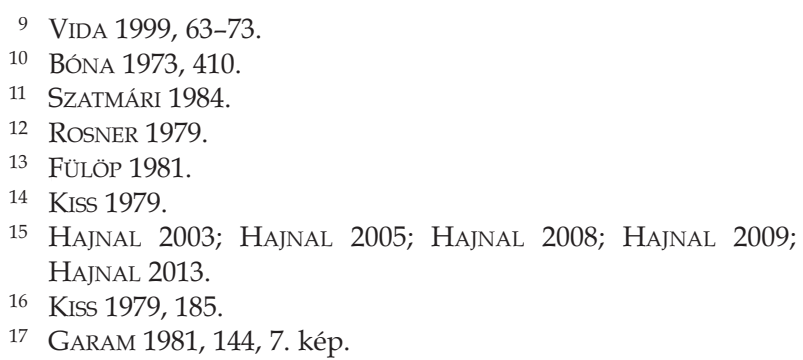


tett térképét is felhasználva vizsgálta a korai avar telepek kérdéskörét. ${ }^{18}$ Összesen tizenegy kora avar kori telepet számláló gyújteményébe - többek között Jozef Zábojník Szlovákiára vonatkozó összefoglaló munkája alapján ${ }^{19}$ - BratislavaRusovce (Oroszvár), Štúrovo-Obid (PárkányEbed), Chl'aba (Helemba) lelóhelyek mellett felvette Keszthely-Fenékpuszta, BalatonmagyaródHídvégpuszta és Nagykanizsa-Inkey sírkápolna lelőhelyeket is. Utóbbit Szőke Béla Miklós az ún. prágai kultúra edényformái alapján a 7 . század második harmadától, közepétől a 7. század végéig keltezte. ${ }^{20}$ Uwe Fiedler lelőhelylistáját tekintve a korainak tartható avar kori telepmaradványok - az erdélyi Moreşti 35. számú gödörházának esetét leszámítva ${ }^{21}$ - a Dunától nyugatra feküdtek. ${ }^{22}$

\section{A 7. századi telepek keltezésének problémája az Alföldön}

A Dunántúlon a késő antik és germán kultúra tárgyi elemei beépültek a lakosság hétköznapi életébe. A települések kerámiaanyagában is megjelennek. Ez a 7. század utolsó harmadáig kimutatható jelenség az avar szállásterület más részein - így a jelen vizsgálatunk tárgyát képező Alföldön - ugyanebben az időszakban nem figyelhető meg. ${ }^{23}$ Míg tehát a Duna mentén és attól nyugatra a kézzel formált kerámia mellett előkerülő korongolt, jó minőségi edények (amforák, korsók, kulacsok, tálak) támpontot adnak a keltezéshez, ${ }^{24}$ addig az Alföldön a megtelepedés kezdeti, 7. századi időszakában szinte kizárólagos a bevándorló avarok gyengébb/rossz minőségú, korongolatlan, pontos keltezésre alkalmatlannak túnő kerámiája. ${ }^{25}$ Következésképpen az Alföld területéról alig ismerünk biztosan a 7 . századra keltezhető települést.

\section{A 7. századi telepek azonosításának támpontjai az Alföldön}

Az alföldi korai telepek értékelése során jelentkező kronológiai problémák megoldásában - szerencsés esetben - alapvetó támpontként a 7. századi kora és középavar kori temetők leleteinek

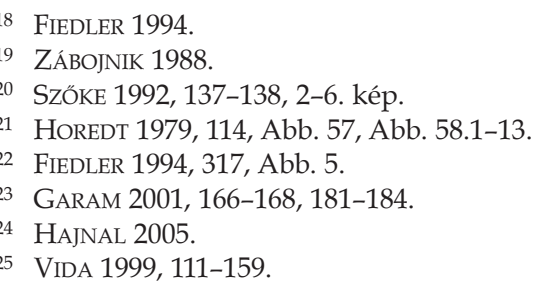

településen való megjelenésére számíthatunk. Az e sírokból származó leletek - a bizonytalanságok ellenére - egyfajta kapcsolódási pontot kínálnak a telepek és az egykorú temetők között, segítve a telepek keltezését. Ezen támpontok között a telepen is feltúnő sírkerámia-típusok töredékei a leggyakoribbak. A típusok vizsgálatánál Vida Tivadar kora és középavar kori sírkerámiákról kialakított megállapításait, csoportbesorolását vehetjük alapul. ${ }^{26}$

A korongon formázott edények közül az Alföld korai településein a Dunaújvárosban is felbukkanó gyorskorongolt szürke kerámia bír korjelző értékkel. Az Alföldön ennek a típusnak a jól iszapolt, vékony falú, zsíros tapintású, világosszürke változata terjedt el (IB2 típus). E díszkerámiatípus különféle változatait gyakran fésús egyenes vagy hullámvonalkötegek díszítik. Keltezése: 6-7. század fordulója - 8. század eleje. ${ }^{27}$

További keltezési támpontként szolgálhatnak a kézzel formált kerámiák között a tölcséres peremú edények hosszúkás, valamint alul kiszélesedő, szúk nyakú változatai (IIIA1-A2 típus). A zömében nagy szemú kerámiazúzalékkal soványított, sárga, sárgásbarna, barnás-vörösessárga színú edényeken csak igen ritkán túnik fel a középavar korra jellemzó függőlegesen lefutó, fésûs vonalkötegdísz (Jászberény-Réti-földek, ${ }^{28}$ Mezőberény ${ }^{29}$ ) vagy fekete színú festés. ${ }^{30}$ Ezeknek az átlagosan 20-30 cm magas edényeknek a felismerése általában jellegzetes peremkiképzésük alapján lehetséges. A csaknem kivétel nélkül az Alföldre jellemzó edénytípus hosszúkás változata mindenütt elterjedt, míg a kiszélesedő, hoszszú, szúk nyakú változat a Tisza és a Maros folyó találkozásának környékén jellemző. A típus a 7. század első évtizedeitől a 7-8. század fordulójáig volt használatban. ${ }^{31}$

A szintén kézzel formált, bütykös vagy csücskös peremú, a szögletes szájú, továbbá a bütykös díszú edények - időrendi besorolásuk miatt szintén a telepobjektumok korai voltát jelezhetik. ${ }^{32} \mathrm{~A}$ típusok mindegyike megtalálható a kora és középavar kori sírokban az Alföldön, döntóen a Duna-Tisza közén. A Kárpát-medencében telepeken is előfordulnak; ${ }^{33}$ az Alföldről példa erre a Karcag-Cseh-sziget 1. házából előkerült szögletes szájú edény. ${ }^{34}$

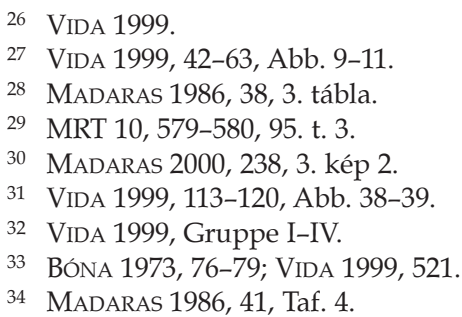

26 VIDA 1999.

VIDA $1999,42-6$

VIDA 1999, Gruppe I-IV.

4 Madaras 1986, 41, Taf. 4. 


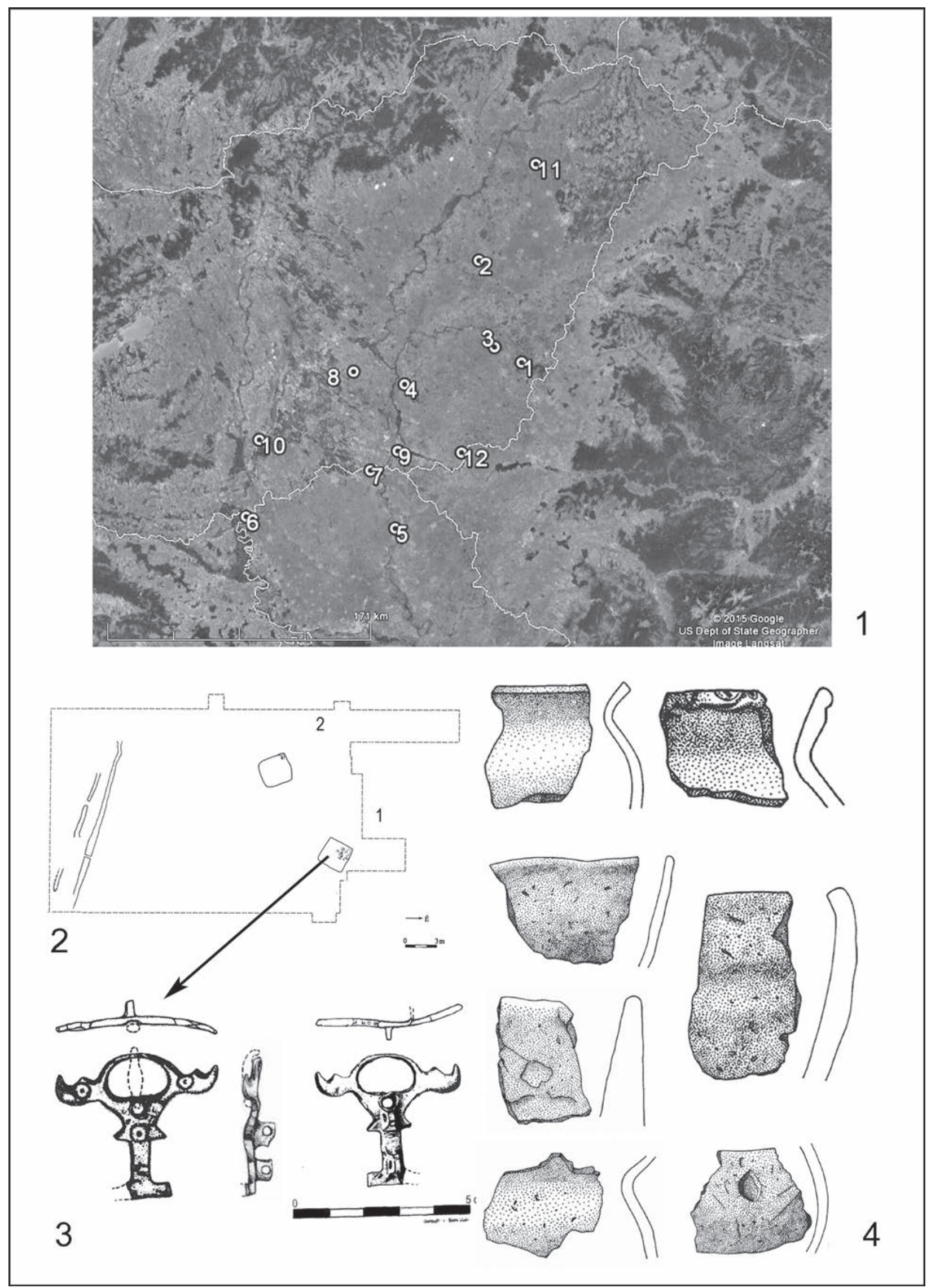


1. kép. 1: 7. századi avar telepek az Alföldön (1. Doboz, 9. ház; 2. Karcag-Cseh-sziget, 1. ház; 3. Mezóberény-Homokbánya; 4. Szentes-Berekhát, Farkas-tanya, 161. ház; 5. Padé/Padej; 6. Küllőd/Kolut-Bačan; 7. Horgos/Horgoš; 8. Kiskunfélegyháza, Pap-dúlő; 9. Szeged-Tápé, SZGT-24. jelú kút építési területe; 10. Nemesnádudvar, Sziget-kaszáló; 11. Hajdúnánás-Verestengerjárás, 1-2. ház; 12. Csanádpalota-országhatár, 230. és 241. ház, 242. kemence); 2: Hajdúnánás-Verestenger-járás lelőhely felszínrajza (FoDOR 2012, 1. kép); 3: Pápa-típusú bizánci tarsolycsat Hajdúnánás-Verestenger-járásról (FoDOR 2012, 10. kép); 4: Edénytöredékek Hajdúnánás-Verestenger-járás lelőhelyról (FoDOR 2012, 1. kép, 7. kép 1-2)

Abb. 1. 1: Siedlungen des 7. Jahrhunderts in der Tiefebene (1. Doboz, Haus 9; 2. Karcag-Cseh-sziget, Haus 1; 3. MezőberényHomokbánya; 4. Szentes-Berekhát, Farkas-tanya, Haus 161; 5. Padé/Padej; 6. Küllőd/Kolut-Bačan; 7. Horgos/Horgoš; 8. Kiskunfélegyháza, Pap-dúlő; 9. Szeged-Tápé; 10. Nemesnádudvar, Sziget-kaszáló; 11. Hajdúnánás-Verestenger-járás, Haus 1-2; 12. Csanádpalota-Staatsgrenze, Haus 230 und 241, Ofen 242); 2: Hajdúnánás-Verestenger-járás, Grundriss des awarenzeitlichen Siedlungsteils (FODOR 2012, Abb. 1); 3: Byzantinische Taschenschnalle vom Typ Pápa aus Hajdúnánás (FodOR 2012, Abb. 10); 4: Gefäßfragmente aus Hajdúnánás (FodOR 2012, Abb. 1, Abb. 7.1-2)

A kora avar kori telepek keresése közben számolnunk kell a helyi gepida fazekastradíciók, valamint a germán hagyományok avar kori továbbélésének lehetóségével. Formai és technológiai értelemben ezt először Rózsa Zoltán vetette fel az Orosháza 13. lelóhely avar kori településén feltárt gyorskorongolt kerámia jellegzetességei (késsel faragott talprész, zsineg használata, faragott oldalfal) kapcsán. ${ }^{35}$ A gepida kori fazekasjegyek felismerése és leválasztása az avar kori települések leletanyagában támpontot kínálhat az alföldi korai települések azonosításához. Ebben a tekintetben számolnunk kell olyan, az Avar Kaganátusba betagozódó gepida csoportokkal, amelyeknek települései - a szürke vagy szemcsés szürke kerámiával együtt - megélték a kora avar kort. A helyi gepida edénymúvesség hagyományainak továbbélését néhány újabb, avar kori gepida temetkezésben talált kerámia is megerősíti. A Szihalom-Budaszögön (Heves megye) feltárt, helyben tovább élő gepida közösség temetőjében például két gyorskorongolt agyagbögre került elő. ${ }^{36}$

\section{7. századi telepek az Alföldön}

\section{A korai telepekre vonatkozó topográfiai adatok}

A régészeti topográfiai munkákhoz kapcsolódó terepbejárások során több olyan településnyomot is észleltek, ahol a felszíni gyújtésből származó leletanyag kora avar kori keltezést valószínúsített. A rendelkezésre álló topográfiai kötetek adatait áttekintve úgy túnik, hogy a meghatározás döntóen a gyorskorongolt szürke díszkerámia jelenlétén alapult. ${ }^{37}$ Az MRT 6., a szeghalmi járással foglalkozó kötete csak késő avar kori

\footnotetext{
35 RÓZSA-T. BIRÓ-TUGYA 2011, 109-110.

36 FodOR-VIdA 2013, 5. kép 2, 6. kép 2.

37 MRT 6, 8, 10.
}

lelőhelyeket említ. Az MRT 10., Békés és Békéscsaba környékének régészeti lelőhelyeit bemutató kötete 214 telepet közöl az avar korszakból. Köztük korainak tartható avar kori telepek is szerepelnek. Jankovich B. Dénesnek a Bevezetóben olvasható leírása alapján kora avar kori telepet ott határoztak meg, ahol jellegzetes korongolt, zsíros tapintású szürke kerámiát is találtak a kézzel formált cserepek között. E lelőhelyek száma tizenegy volt. ${ }^{38}$ Békéscsaba határában négy ilyen lelóhely található: Kerek I., ${ }^{39}$ Hosszúsor, Baromfitelep I., ${ }^{40}$ Kesjár-tanya ${ }^{41}$ és Kismegyer VIII. ${ }^{42}$ Csárdaszálláson Félhalom, Gátoldal,43 Kamuton Egyenes-dúlő V., ${ }^{44}$ Kétsoprony környékén Laczó-dúlő I., ${ }^{45}$ Murony határában Soványhát, volt Eiler-major, ${ }^{46}$ Telekgerendáson Felsőnyomás, Molnár-dúlő, ${ }^{47}$ Mezőberény határában Belentai sarok I. ${ }^{48}$ lelóhelyen kerültek elő korai jellegú szürke, hullámvonalkötegekkel díszített cserepek. Jankovich B. Dénes megjegyzi, hogy a korai telepek száma nagyobb lehet, leválasztásuk azonban a pontosabb keltezéshez szükséges támpontok hiányában problémás. ${ }^{49}$

$\mathrm{Az}$ MRT 8., Békés megye szarvasi járását feldolgozó kötete szintén a szürke kerámiára alapozva közöl kora avar kori településnyomokat: Csabacsúdön Kita-tanyán, ${ }^{50}$ Endrődön Öregszőlők I. és Nadrág-fok lelóhelyeken, ${ }^{51}$ Gyomán

\footnotetext{
38 MRT 10, 719.

39 MRT 10, 156-157.

40 MRT 10, 282.

41 MRT 10, 285.

42 MRT 10, 287.

43 MRT 10, 456.

44 MRT 10, 477.

45 MRT 10, 500.

46 MRT 10, 628.

47 MRT 10, 690.

48 MRT 10, 559.

9 MRT 10, 24.

50 MRT 8, 117.

51 MRT 8, 141.
} 
a Balai rév és a Fattyas-sarok, Márton-tanya mellett, ${ }^{52}$ valamint Fattyasi digó ${ }^{53}$ lelóhelyeken.

Részben az MRT-kötetek adatait felhasználva találunk adatokat Szentpéteri József 2002-ben megjelent adattárának második kötetében. A Kárpát-medencében felgyújtött avar kori települések között 83 lelóhely kapcsán merült fel a 7. századi keltezés lehetősége. ${ }^{54}$ Ebből 26 lelőhely esik az Alföld területére. A szóba jöhető lelőhelyek közül még kevesebbet tartanak határozottan 7. századinak (16 lelőhely). A terepbejárásból származó adatok mellett a kötet néhány kora avar korinak tartott településre vonatkozó ásatási adattal is szolgál (Jászberény-Réti-földek, Mezőberény-Homokbánya).

\section{A korai telepekre vonatkozó ásatási adatok}

A topográfiai adatok mellett biztosabb forrásértékkel rendelkeznek azok az ásatásokról szóló közlések, amelyek zárt objektumból elókerült leletekről számolnak be. Ezek száma a 8-9. századi alföldi telepközlések számához képest igen szerénynek mondható, és sok esetben magukban hordozzák a keltezés bizonytalanságát. Az alábbiakban ezeket tekintjük át (1. kép 1).

1. Doboz, 9. ház (Békés megye). Adataim alapján az Alföldről az első, bár kissé bizonytalan megítélésú, talán 7. századinak tartható telepobjektumokról szóló közlés 1975-ben jelent meg. A Kovalovszki Júlia által előzetes jelentésként publikált dobozi Árpád-kori telepen számos olyan épületről olvashatunk, amelyben kizárólag kézzel formált kerámia volt. Különösen a telep 9. számú, északkelet-délnyugati tájolású, két oszlophelyes, északi sarkában kemencés, középen túzhelyet rejtó háza kapcsán merült fel az avar kori keltezés lehetősége. A betöltésben tál, sütőharang, tölcséresen kihajló peremú edények töredékei voltak. Az utóbbi edénytípusról szóló adatok Doboz esetében talán megengedik a tágabb 7. századi keltezést. ${ }^{55}$

2. Karcag-Cseh-sziget, 1. ház (Jász-NagykunSzolnok megye). A lelőhelyen 1982-ben végzett ásatást Madaras László. Egy 3×3 méteres, négyzetes, északnyugat-délkeleti tájolású épületet tárt fel. A házban egymással szemben cölöphelyek feküdtek, a délkeleti sarok közelében túzhely és két edény. Az egyik egy kézzel formált, szögletes szájú, ujjbenyomkodással tagolt pere-

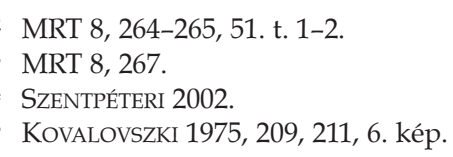

mú, vállában szélesedő fazék volt, a másik egy lassúkorongolt, fésús hullámvonallal, alatta egyenes vonalkötegekkel díszített fazék. Madaras László az utóbbi edény alapján a 8. század első felére keltezi a házat. ${ }^{56} \mathrm{~A}$ szögletes szájú edény alapján nem kizárható a korábbi, 7. század végére való datálás sem.

3. Mezőberény-Homokbánya (Békés megye). Az MRT 10. kötetében 1999-ben közzétett Mezőberény-Homokbánya lelőhelyen három gödör került elő. ${ }^{57} \mathrm{Az}$ egyetlen kibontott verem tüzelőgödörnek bizonyult. ${ }^{58}$ Ebben egy edényt találtak. A fazék korongolatlan, barna színú, tölcséres nyakú, feneke felé kissé összeszúküuoo. Oldalán durván bekarcolt férfi- és női alak látszik. ${ }^{59} \mathrm{Az}$ emberalakoktól balra, azokkal egy magasságban benyomott pontokból álló díszítósor látszik, a figuráktól jobbra, egymástól különböző távolságokra, az edény vállán pedig három függőlegesen bekarcolt vonalköteg. Az emberalakokkal átellenes oldalon, az edény alján benyomkodott pontkörös minta van. Az edény formája alapján a kora avar kori tölcséres nyakú típusba tartozik, így a gödör a 6-7. századra keltezhetó. ${ }^{60} \mathrm{Az}$ ovális tüzelőgödör keményre égett aljába hasonló, tölcséres edénytöredékek voltak betapasztva. ${ }^{61}$

4. Szentes-Berekhát, Farkas-tanya, 161. ház (Csongrád megye). A 2000-ben Madaras László által közzétett lelőhelyen egy korainak tartható épületet tártak fel. Az ásatás leletben leggazdagabb 161. házának verme 2,5×2,5 m nagyságú volt. Keleti és nyugati oldalfalának közepén egyegy oszlophely került elő. A paticsos betöltésben bikónikus és nyomott gömbös orsógomb, kézzel formált tál, sütőharang, függőlegesen fekete sávokkal festett fazékperem, talán egy pohár és ovális halsütő edény töredékei voltak. Utóbbin a fazekaknál is megfigyelt ujjbenyomkodás mellett $-3 \mathrm{~cm}$-rel a perem fölé magasodó fül vagy fogantyú maradt meg. A kézzel formált töredékek mellett azonban jellegzetes szürke színú, gyorskorongolt, vonal- és hullámvonaldíszes díszkerámia töredékeit is megtaláljuk. Madaras László az avar kori települést a 7-8. század fordulójára, a 161. házat pedig a benne talált festett, korong használata nélkül készült kerámia alapján a település 7 . századi időszakára datálta. ${ }^{62}$ A szürke díszkerámia jelenléte szintén ezt a keltezést erősíti.

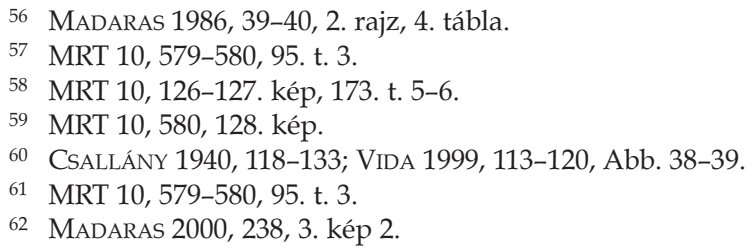


5. Padé (Padej, Szerbia). A 6. század végére, a 7. század elejére keltezett Padé/Padej településről a korongolatlan sütőharangok, fedők és lapos tálak mellett (a mezóberényi vagy a dobozi telepen szintén megfigyelt) tölcséres peremú edények is ismertek. ${ }^{63} \mathrm{~A}$ településrészen vízszintesen bekarcolt vonalakkal és a perem alatt pecsételéssel díszített kerámia is előkerült. ${ }^{64}$

6. Küllőd (Kolut-Bačan, Szerbia). A padéi teleppel közel egykorúnak tartható a Küllődről közölt településrészlet. Itt a korongolatlan edények között magas, tölcséres peremú hombárok, egy bütyökdíszes tál, valamint fedők és sütőharang töredékei voltak. Kialakításuk megegyezik a magyarországi kora avar kori kerámiák kialakításával. ${ }^{65}$

7. Horgos (Horgoš, Szerbia). Az egykori ármentes szigeten található település anyagában a korongolatlan kerámiák között tölcséres peremú hombárokat, sütőharang-, fedő- és táltöredékeket találtak. A település objektumainak egy része így a kora avar korra keltezhetó. ${ }^{66}$

8. Kiskunfélegyháza, Pap-dülő (Bács-Kiskun megye). 2002-ben Kiskunfélegyházától délkeletre, egykor vízállásos területekkel övezett földháton egy avar teleprészletet tártak fel. A $13500 \mathrm{~m}^{2}$ alapterületú szelvényben laza szerkezetú „nomád szállás nyomai" mutatkoztak. A gödrök és a téglalap alakú karámok között kerek felszíni építményekre utaló cölöphelyekre bukkantak, amelyeket jurtahelyekként határoztak meg. A kerámiazúzalékkal soványított, kézzel formált edények mellett azonban feltúntek a szürke, homokos soványítású, korongolt, bekarcolt hullám- és egyenes vonalköteggel díszített díszkerámia töredékei is. A telepen teljesen hiányoztak a sütőharangok és a bográcstöredékek. Mindezek alapján az ásató a részleteiben közöletlen telepet az avar kor korábbi, 7. századi periódusára keltezte. ${ }^{67}$

9. Szeged-Tápé, SZGT-24. jelü kút épitési területe (Csongrád megye). 2008-ban Tápétól északra, a Tiszát kísérő egykori magasparton fekvő, több korszakot rejtő, blokkszerú szelvény északi szélén és annak középső részén avar kori objektumok jelentkeztek. ${ }^{68}$ A két, egymástól 35 méterre található objektumcsoport egy-egy kemence körül összpontosult. Mindkét kemence szögletes

\footnotetext{
63 TrifunOVić 2000, 104, Tab. XX.1, 32; Vida 2011, 727.

64 IVANIŠEVIĆ-BUGARSKI 2008, 52, fig. 12.

65 TRIFUNOVIĆ 2000, 95, 99; VIDA 2011, 727.

66 TRIFUNOVIĆ 2000, 99; VIDA 2011, 727.

67 BALOGH 2002, 227-228.

68 A Tápéi-főcsatornáig húzódó, a 86. sz. kútkörzet területét érintő lelőhelyen Gulyás Gyöngyi vezetésével és jelen sorok írójának részvételével zajlottak a feltárások. Az ásatás részleteiben közöletlen.
}

előtérrel rendelkezett, az egyik középen oszlophellyel. A kemencék sütőfelületében kézzel formált kerámia- és őrlőkő-töredékek voltak. Az objektumokból kézzel formált edények töredékei kerültek elő, köztük tölcséres szájú hombár-, sütőharang- és fazéktöredékek. A telep 7. századi keltezését támogatja, hogy egy gödörben gyorskorongolt, vékony falú, szürke színú, vízszintes és hullámos vonalköteggel díszített oldaltöredéket is találtak. ${ }^{69}$

10. Nemesnádudvar, Sziget-kaszáló (Bács-Kiskun megye). A lelőhelyen egy $6667 \mathrm{~m}^{2}$ alapterületú szelvényben feltárt avar kori településrészlethez három kerítóárok, egy rövid árokszakasz, két körárok, két ház, 28 gödör, valamint egy kút tartozott. $^{70} \mathrm{~A}$ házakban sem tapasztott padló, sem túzhely nem volt. A kútból faragott fa késnyél került elő, egy gödörből szenült növényi maradványok. A telep gazdag leletekben. A kerámiaanyagban megtalálhatóak a gyorskorongolt, jól égetett, vékony falú edények vörös és szürke színú töredékei, amelyeken egyenes és hullámos vonalkötegdísz látható. A kézzel formált edényeken feltûnnek a benyomkodott és bekarcolt vonalakkal díszített peremek is. A telepen bronzlemezt, vaskést, vasárat, továbbá egy szemesgyöngyöt is találtak, amely alapján az ásató a telepet a 7. század első felére keltezte. ${ }^{71}$

11. Hajdúnánás-Verestenger-járás, 1-2. ház (Hajdú-Bihar megye). Hajdúnánástól 4 kilométerre nyugatra két ház és két árokrészlet került eló. A két, egymástól 6,5 méterre fekvő ház téglalap alaprajzú, alapterületük $7,1 \mathrm{~m}^{2}$ és $6,75 \mathrm{~m}^{2}(252 \times 285$ $\mathrm{cm}$ és $270 \times 250 \mathrm{~cm}$ ) (1. kép 2). Cölöphelyeknek nem maradt nyoma, így tájolásuk kérdéses. Mindkét házban patkó alakú agyagtömbbe vájt kemence foglalta el az északnyugati sarkot. Az első ház kemencéjének szájrésze előtt, az átégett padlón ovális alakú, kiöntőfüles agyagtepsi töredékeit, a második házban kőboltozatra utaló kődarabokat találtak a kemence túzterében. A kerámia leletanyag kizárólag kézzel formált, murva és csillám soványítású, egyenetlen kiégetésú, szürkés-barnás színú edénytöredékekből állt (1. kép 4). Ezek között enyhén kihajló, benyomkodással tagolt peremek is vannak. A keltezésben döntő érv az első házból előkerült Pápa-típusú, így a 7. század elejére keltezhető bizánci típusú bronz tarsolycsat (1. kép 3). A leletanyag összetétele alapján Fodor István a lakóházakat a 7. századra keltezte. $^{72}$

69 Gulyás 2009, 286-287.

70 Somogyvári Ágnes 2009-ben vezetett feltárása. Az ásatás részleteiben közöletlen.

71 SOMOgYVÁRI 2009, 293.

72 FODOR 2012. 


\section{Csanádpalota-országhatár (Csongrád megye)}

A Makótól keletre fekvő Csanádpalota-országhatár lelőhelyen $44553 \mathrm{~m}^{2}$ alapterületen végeztünk teljes körü feltárást. ${ }^{73}$ A területen észlelt 497 objektum közül csupán két háznyom és két kültéri kemencebokor képviselte az avar kori telepet (2. kép 1-5).

Az 1984 óta ismert lelóhely Csanádpalota déli határában található, a településtől mintegy 3 kilométerre délre. A környék meghatározó vízfolyása a Krakk-ér, amely a II. katonai felmérésen Pitvarostól délre „ered”, és Nagylaknál a Marosba folyik, ahol a Csid-ere nevet viseli. A Krakk-ér átlagosan 100-150 méter szélesen kanyargó, közel észak-déli irányú medrének sávjától keletre elterülő lelóhelyen a terepbejárások során avar korra utaló leleteket nem találtak. Ezeket csak a régészeti feltárás során észleltük.

A kora avar kori telepjelenségek - két külső kemencéből és egy közös munkagödörból álló kemencebokor (226. és 144. objektum), két lakóház és az egyik házra települt külső kemence - a Krakk-ér medrének partjától 60-80 méterre, az eret kísérő dombhát magaslati részén feküdtek, egy észak-déli irányú tengely mentén (2. kép 5). A 241. objektumtól északra, már a szelvényfal mellett fekvő 230. sz. házra utólag egy kemence települt, a ház felhagyott lakógödrét munka-/ előtérgödörnek használva (242. objektum). A ház és a kemence előterének hasonló leletanyagát csak részben tudtuk elkülöníteni. A két épület között két kemencéből álló kemencebokor került elő (144. és 226. objektum). Az egymástól 18 méterre álló lakóépületek közvetlen közelében szarmata és Árpád-kori objektumokat, valamint újkori beásásokat tártunk fel. Ez utóbbiak az avar jelenségeket nem bolygatták meg, bár az avar kori jelenségekhez közeli egyik újkori árokban néhány avar kori kerámiatöredék is volt.

Az egykori avar településhez tartozó két épület (241. és 230. objektum), a 230. sz. épületre ásott munkagödör, az ahhoz északon kapcsolódó túztér (242. objektum), valamint a kemencebokor (144. és 226. objektum) az ásatási szelvény északi szélén feküdtek. A megkutatott felület határait és az objektumok helyzetét ismerve bizonyos, hogy a telep csak északi irányban folytatódhat az egykori vízjárta Krakk-ér ármentes partján. A kutatást azonban ebben az irányban nem lehetett ki-

73 A feltárás a szegedi Móra Ferenc Múzeum munkatársainak együttmúködésével 2010. október 26. és 2012. december 7. között folyt. A felületen kora bronzkori telepjelenségek és sírok, szarmata telep és temetőhöz kapcsolható objektumok, avar sírok és telepjelenségek, valamint egy kiterjedt Árpádkori település objektumai kerültek elő. terjeszteni. Feltúnő, hogy a feltárt felületen sem árok, sem gödör nem került elő. Az avar telepek ismeretében ez szokatlannak mondható. Kérdéses a telep fennállásának ideje is. A 230. házveremre ásott kemence és a kemencebokor arról tanúskodnak, hogy a telepet hosszabb ideig is lakhatták, vagy lakói visszatértek erre a helyre.

\section{Lakóházak és szabadtéri kemencék}

Két, félig földbe mélyített épület esett a feltárás területére (241. és 230. objektum). Mindkét ház kissé szabálytalan, négyszög alakú foltja a mai felszín alatt 60-70 cm mélyen jelentkezett. A 241. épület téglalap alaprajzú vermének alapterülete $7,8 \mathrm{~m}^{2}$, a 230 . ház szintén téglalap alaprajzú vermének alapterülete $11,6 \mathrm{~m}^{2}$ volt (3. kép 1; 4. kép 1). Mélységük közel azonos, átlag $45 \mathrm{~cm}$. Tekintve a talaj kötött szerkezetét, az avar korban a házak vermének mélysége 100-110 cm körül lehetett. A két ház tájolása eltérő volt. Erre a veremformán túl a mindkét házban megfigyelt, a tetőt tartó ágasfák vagy oszlopok nyomait jelző beásások utaltak. A szelvényünk középtengelyéhez közelebbi 241. épület oromzatát a két hosszanti oldal középső harmadába ásott oszlophelyek tanúsága alapján északnyugat-délkeleti irányban tájolták. A tóle 18 méterre északra álló 230. épület ezzel szemben - a rövid oldalakon lelt oszlophelyek alapján - kelet-nyugati hossztengelyú volt. Mindkét ház padlója kisebb mértékben volt lejárva, tapasztás egyikben sem mutatkozott. A házakban épített kemence vagy "szabad túzhelyre” utaló átégett felület nyomát nem találtuk.

A 230. házra ásott 242. sz. kemence egyszerú felépítésú. Előterét a felhagyott ház vermének keleti végére telepítették észak-déli tengelyben, északon bevájt túztérrel. Az előtér kemence felöli északi vége szögletes volt. A sütőfelületben kerámiaréteg nem mutatkozott. A két ház között előkerült kemencebokor (144. és 226. objektum) egy szabadban álló kemence egyszeri megújításából jöhetett létre, de nem kizárt a két kemence azonos időben való használata sem. Az ovális előtérgödörhöz északról és nyugatról egy-egy, a házveremre telepített kemencével azonos szerkezetú, ovális alakú, lapos sütőfelület csatlakozott. Kerámiaréteget ezekbe sem fektettek.

\section{A leletanyag értékelése}

A feltárt objektumokból - a településeken megszokott módon - főként kerámiatöredékek kerültek elő. Ez összeállítás nélkül 114 töredéket jelent (összeállítva 106), amely mindösszesen $6,64 \mathrm{~kg}$ tömegú volt. A betöltésben emellett állatcsontot, 
követ és paticstöredékeket is találtunk. A teleprészlet legjelentósebb lelete egy avar kori préselt övveret volt. ${ }^{74}$

\section{Tarnaméra-típusú szíjvég (3. kép 2) ${ }^{75}$}

Nem túl gyakori jelenség, hogy egy jól keltezhetó fémtárgy kerül elő avar kori telepen (Tatabánya, ${ }^{76}$ Komárom, ${ }^{77}$ Hajdúnánás ${ }^{78}$ ). Jelen esetben a 241. ház gödrének közepén, a padlószint felett, annál 20-30 cm-rel magasabban egy Tarnaméra-típusú nagyszíjvég került elő, igen jó állapotban. Az ebbe a típusba tartozó, préselt bronzlemezből készült, lehajlított oldalú nagyszíjvégek alapmotívuma a középső kerek rozetta, valamint a pontés vessződíszítés, amely a mélyebb árkolással körbevett, nyitott végú, csepp alakú mintát kereteli. A Tarnaméra-típus az úgynevezett Törökkanizsa-típusú, eredeti bizánci övdíszek keresztény vonatkozású szimbólumait utánozza. A lelóhelyünkön talált példányon középen látható kereszt (az eredeti Krisztus-monogram másolata), illetve a keretelt, csepp alakú minta (ciprusmotívum) is ezen elóképek alapján készültt. ${ }^{79}$

A Kárpát-medencében csekély az ilyen típusú veretek száma. Garam Éva tizenöt sírból közöl példányokat. Adataim alapján a csanádpalotai példány az első, amelyet telepobjektum rejtett. Pontos analógiáját nem találtam. A jól körülírt típus legközelebbi párhuzamai Szeged-CsengeleFeketehalom 59. sírjából, ${ }^{80}$ továbbá Szeged-Kundomb 180. és 289. sírjából kerültek elő. ${ }^{81} \mathrm{Az}$ Alföldről további példányok ismertek Tarnaméra-Urak-dúlő 1. és 10. sírjából, ${ }^{82}$ TiszafüredMajoros 776. sírjából ${ }^{83}$ és Jánoshida-Tótkérpuszta 26. sírjából. ${ }^{84} \mathrm{~A}$ romániai Fönlakon a forma préselőverete is felbukkant. ${ }^{85} \mathrm{~A}$ keltezés szempontjából különös fontosságú Szeged-Kundomb

74 A leleteket a Móra Ferenc Múzeum restaurátorai, Dobó Bernadett, Vidovics Teréz, Borbíró Márta és Fekete Lajosné restaurálták. A tárgyfotók és a profilrajzok nagy részét a feltárásban is részt vevő Takács Gábor és Gyưrösi Tímea készítette. Munkájukat ezúton is köszönöm.

75 A veret előkerülésének pontos helyét Ács Mihály ásatási munkás elbeszéléséből ismerjük, aki a korrodált leletet kezdetben konzervdoboz darabjának vélte. A veret fotóit Takács Gábor, a feltáráson részt vevő ásatási technikus készítette. Munkáját ezúton is köszönöm.

76 SZATMÁRI 1984, 73, 77, 17. kép.

77 TRugly 1996, 139, 18. kép.

78 FODOR 2012, 717, 10. kép.

79 Garam 2001, 141-143, Taf. 104-107.

80 TÖRÖK 1984, VII. t. 17

1 Salamon-Sebestyén 1995, 28, Pl. 25, 37, Pl. 36.1-2.

2 SZABÓ 1965, 33, Taf. III, X, 42, Taf. VII.1-5, Taf. X.

GARAM 1995, 96, Taf. 119.

ERDÉLYI 1958, 10-11, Taf. XII.1-2, 6

FETTich 1926, Taf. 6.2.
289. sírja, ahol az övgarnitúrán a 7. század első harmadában divatos, a 7. század közepéig használt fönlaki típusú veretek is voltak. A Tarnamératípusú és Pápa-típusú veretekkel díszített övek viselői gyakran fegyvermelléklettel ellátott sírokban nyugodtak. A Tarnaméra-típusú övdíszek a 7. század második harmadában voltak divatban. Használatuk felső határát Garam Éva - a tiszafüredi 776. sír és a jánoshidai 26. sír ezüstözött övvereteire alapozva - a 7. század közepére határozta meg, ${ }^{86}$ tehát igen jó keltező értékú tárgytípusról van szó.

\section{Szürke díszkerámia}

A 241. ház betöltéséből két szürke korongolt díszkerámia töredéke is napvilágot látott (3. kép 3-4). A két töredék tömege csupán $32 \mathrm{~g}$, jelentôségük mégis nagy, hiszen a jellegzetes 7 . századi díszkerámia és a Tarnaméra-típusú veret együttes előfordulása a telep 7. századi keltezésének újabb bizonyítéka. Korukat a 6-7. század fordulójától a 8. század kezdetéig tehetjük. ${ }^{87} \mathrm{~A}$ tapintásra gipszszerú, soványítás nélküli, a nagyobb töredék esetében kívül formázófával elkent, eszköznyomos felületú, belül korongnyomos töredékek eltérnek a szarmata, nagyobb fajsúlyú szürke töredékek megjelenésétől. Egy ilyen, egyértelmúen szürke szarmata edényoldalból faragott orsókarika szintén a ház leletei közé tartozott (3. kép 8). Nem kizárt, hogy az itt lakó avar kori népesség a környéken egykor elterülő szarmata telepról gyújtötte be a szóban forgó tárgyat.

\section{Kézzel formált kerámia}

Az objektumok betöltésének kerámialeletei technológiai szempontból egységes képet mutatnak. A kerámiatöredék zöme ugyanis (112 db) kézzel formált edény része volt. A legtöbb feltehetően fazékból származik, de mellettük sütóharangok (14 db, 13\%) és egy tál töredékei is felbukkannak. A töredékek között nagyobb tárolóedény darabjai is sejthetôk. A cserépbográcsok jelenléte kérdéses, csupán egy peremtöredék kapcsán merült fel. Az egyenes állású, az edény belső oldala felé ferdén lecsapott szélú töredék ilyen edényhez is tartozhatott (5. kép 4). Az edények anyaga döntően durva szemú kerámiazúzalékkal erósen soványított, amelybe némi szerves anyag is vegyült. Adalék anyagként elvétve homokot is kevertek az agyagba (11\%), néha pedig csak homok a soványító anyag (3\%). Néhány edény felületén

86 GARAM 2001, 144-146.

87 VIDA 1999, 42-63, Abb. 9-11. 


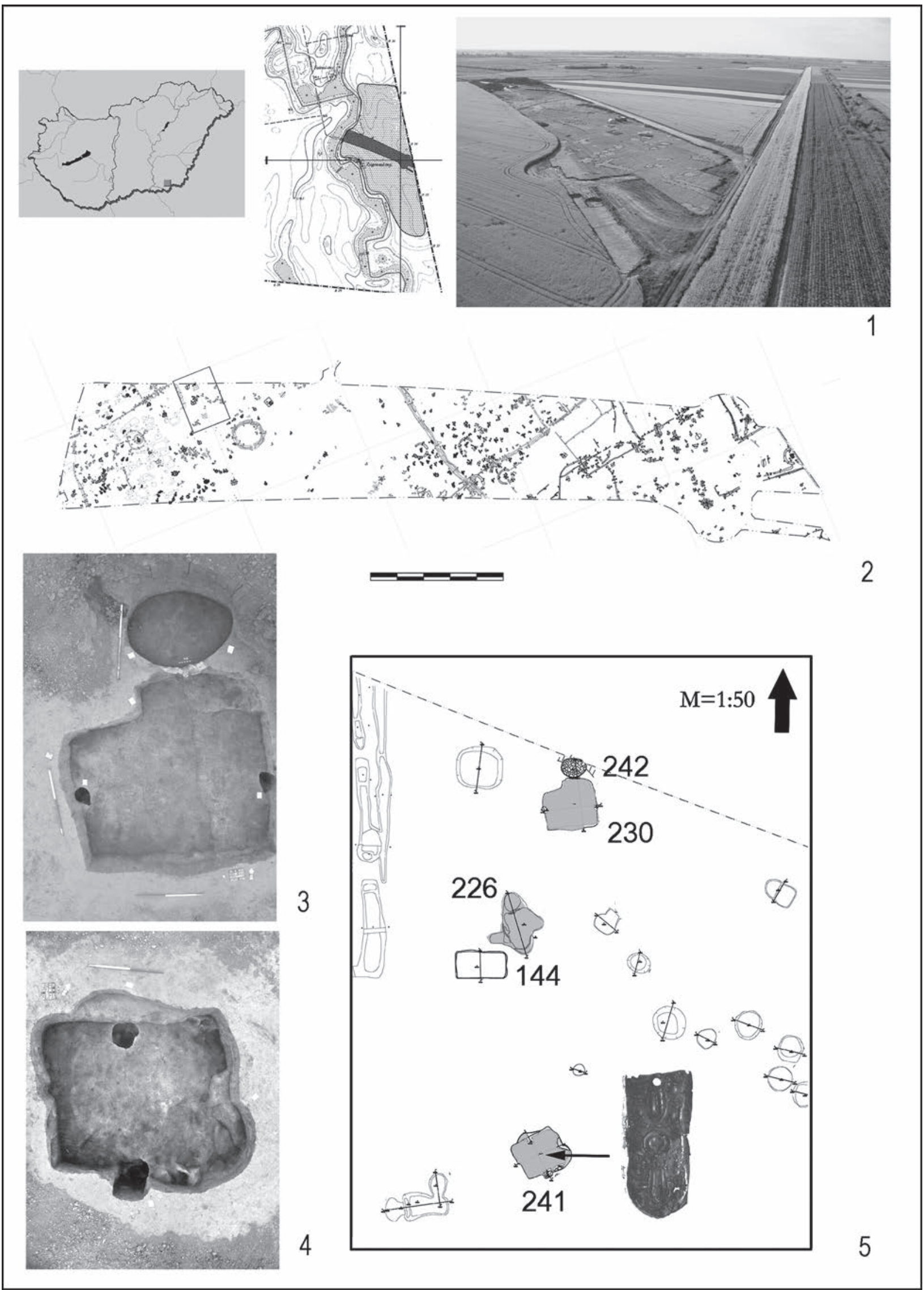

2. kép. Csanádpalota-országhatár. 1: A lelőhely elhelyezkedése; 2, 5: az avar településobjektumok helyzete a szelvényben; 3: 242. kemence és 230. ház; 4: 241. ház

Abb 2. Csanádpalota-Staatsgrenze. 1: Die Lage des Fundortes; 2, 5: Position der awarischen Siedlungsobjekte auf der Grabungsfläche; 3: Ofen 242 und Haus 230; 4: Haus 241 


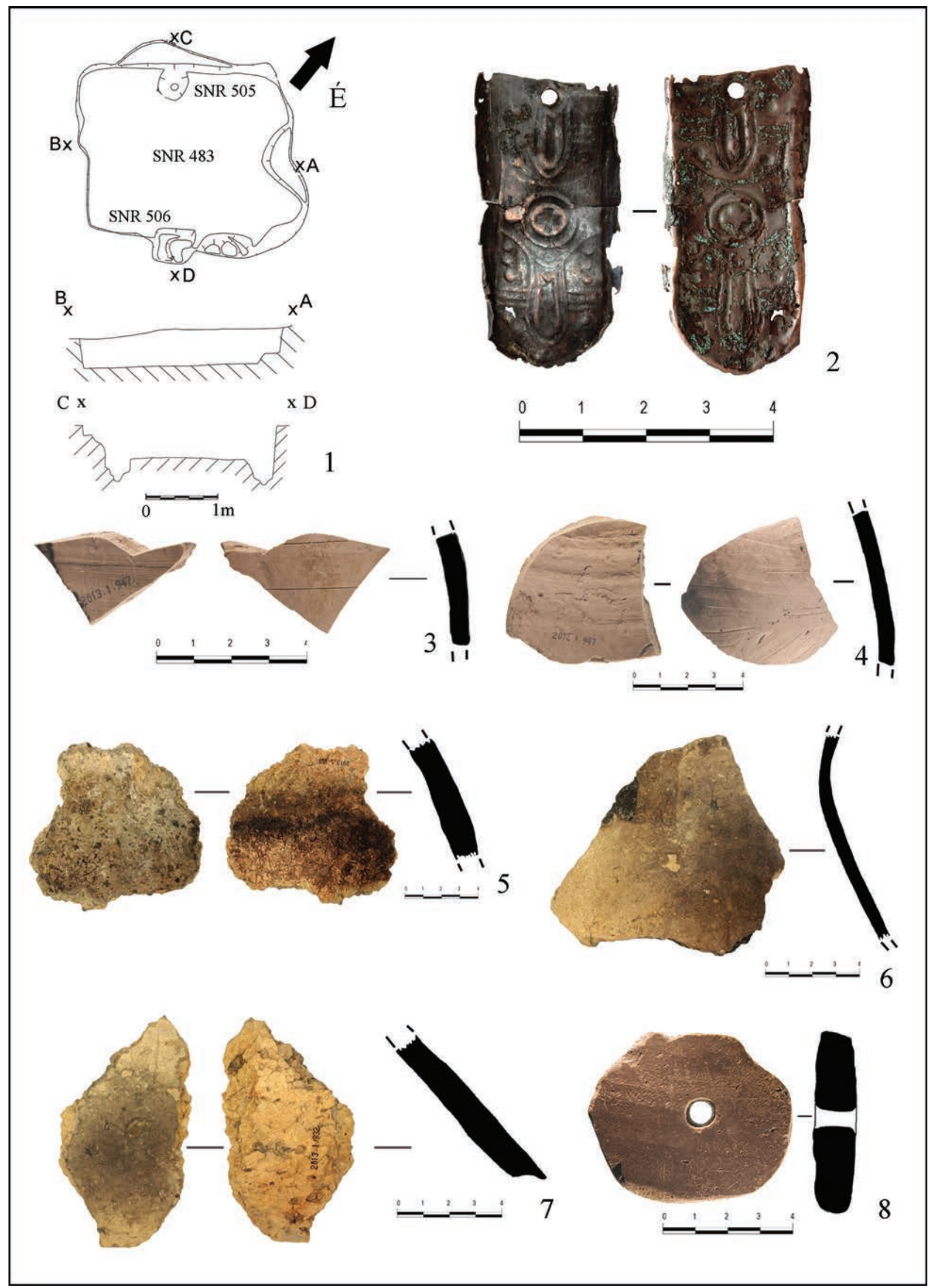

3. kép. Csanádpalota-országhatár. 1-8: A 241. ház alaprajza és leletei

Abb. 3. Csanádpalota-Staatsgrenze. 1-8: Der Grundriss des Hauses 241 und die Funde 

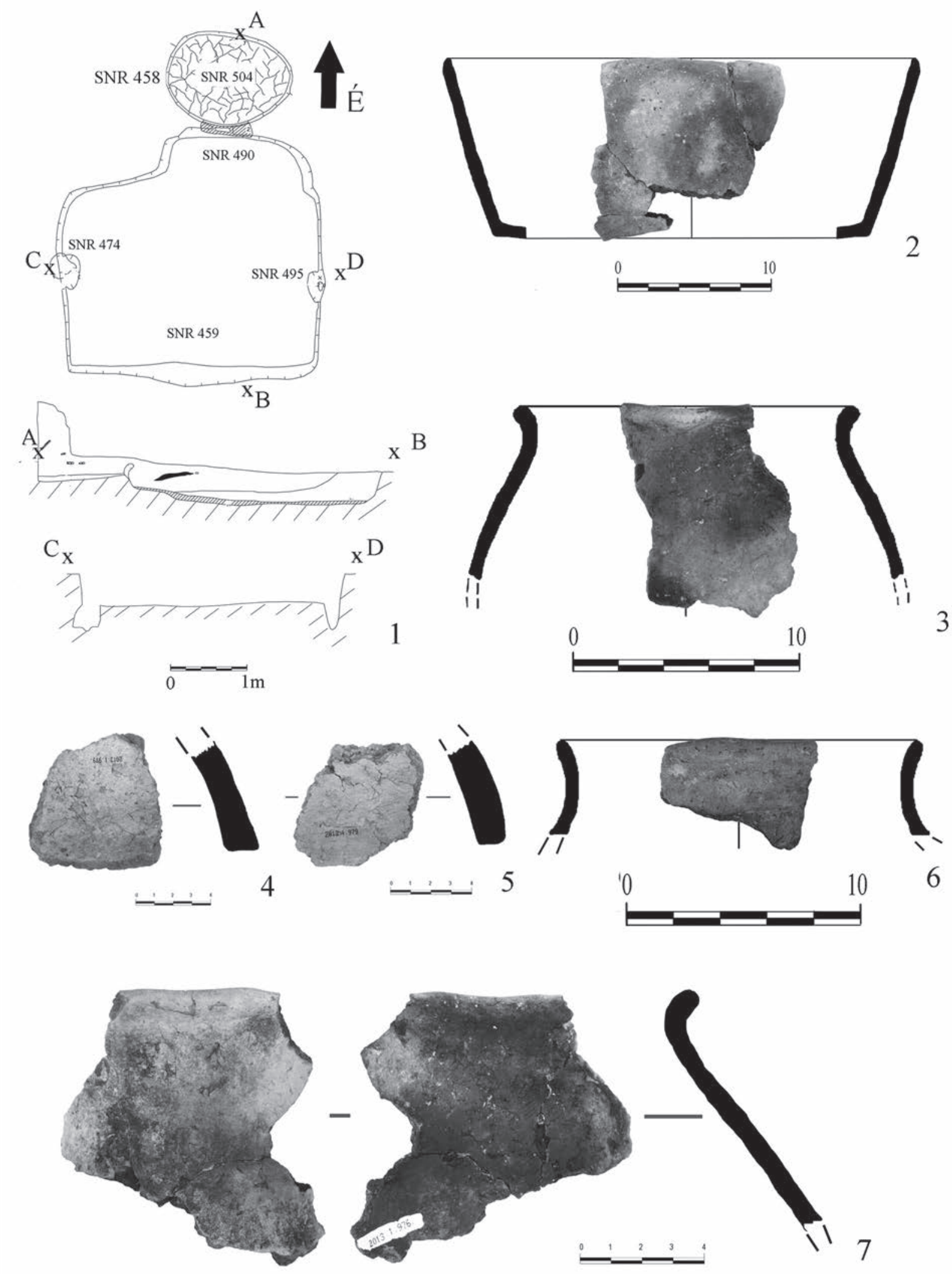

7

4. kép. Csanádpalota-országhatár. 1-7: A 230. ház alaprajza és leletei

Abb 4. Csanádpalota-Staatsgrenze. 1-7: Der Grundriss des Hauses 230 und die Funde 
szerves anyag lenyomatai láthatóak (5. kép 3). A felületek elkentek, elnagyolt kidolgozásúak. Díszítésnek sajnos egyik edénytöredéken sem találtuk nyomát. Az edények szürke foltos barnásvöröses színe az alacsony hőfokon történő égetésre utal.

A fazekak peremei röviden kihajlóak, íveltek (4. kép 3, 7), emellett 2-4 cm magas tölcséres kialakítás is előfordult (4. kép 6; 5. kép 5). A peremátmérők mért értékei $15 \mathrm{~cm}$ körül szóródtak, bár a mérhető példányok száma igen alacsony. $\mathrm{Az}$ edények falvastagsága 0,6-1,2 cm körül ingadozott. Teljes profil hiányában a fazekak magassága nem ismert. A peremek alapján alacsony és középmagas edények valószínúsíthetók. Az edények kidolgozása közepes, belül szinte minden esetben durva, kissé hullámos a felület. A külső felületek jobban eldolgozottak. A töredékek színe belül sötétebb, szürke, szürkésbarna, kívül a barna árnyalatai dominálnak. Gyakori a világos színárnyalat és a foltosság.

A sütőharangok töredékeinek anyagát cseréptörmelékkel és néha kevés szerves anyaggal soványították. A tizennégy töredék tömege $0,9 \mathrm{~kg}$ volt. A belül vöröses, kívül világosbarna színú példányok peremátmérője $30-40 \mathrm{~cm}$ körül lehetett. A peremszélek laposra vágottak (5. kép 3) vagy lekerekítettek (4. kép 5). A falvastagság, zömök edényekről lévén szó, 1,3-2,2 cm között ingadozott. A töredékek belsó oldalán minden esetben durván simított a felület. A formázáskor használt textil lenyomata egy töredéken sem volt látható. Fogófülre utaló töredékek a 241. házból kerültek elő. Ezek $5 \mathrm{~cm}$ széles és $4 \mathrm{~cm}$ magas, lekerekített trapezoid átmetszetú hurkafülek voltak.

A telepen tálakat is használtak. Erre bizonyíték a 242. kemence túzterében és előterében szétszóródott lapos, tölcséresen kihajló falú példány töredéke (4. kép 2). A teljes profilú, nagyobb méretú tál méreteit is ismerjük. Peremátmérője $30 \mathrm{~cm}$, magassága $10 \mathrm{~cm}$, fenékátmérője $25 \mathrm{~cm}$ körül volt; falvastagsága egyenletes, $1 \mathrm{~cm}$. Ferdén kidőlő pereme lekerekített szélú. Teljes profiljának köszönhetóen számítható úrtartalma jelentős, közel 6,8 literre tehető. Kidolgozása gondosabb, felülete kívül-belül simított. Szerkezetében nagyon hasonló agyagtálak ismertek Dobozról, a 9. házból. ${ }^{88}$

\section{Paticsok és kövek}

Paticsokat minden objektumban találtunk. Ezek összsúlya nem jelentős, 200 g körüli. Többnek a felületén koromnyomok és növényi lenyomatok

88 KovalovszKi 1975, 14. kép 9-10. vannak. Jelenlétük talán a házak épített falazatára utal, bár hozzá kell tenni, hogy a házak leégésére vonatkozó nyomokat nem sikerült rögzíteni. Köveket csak a 241. ház betöltésében találtunk. $\mathrm{Az}$ összesen $135 \mathrm{~g}$ kőanyag egy része - a lecsiszolt felületek alapján - fenőkő lehetett.

\section{Állatcsontok ${ }^{89}$}

Az avar telepen előkerült háziállat-maradványok között szarvasmarha (Bos taurus), sertés (Sus domesticus) és ló (Equus caballus) maradványait lehetett azonosítani. A maradványokon táplálék célú feldolgozásra utaló jelek figyelhetők meg, azaz égés (241. ház) és vágás nyomai (242. kemence). A 230. házban talált szarvasmarha-maradványok mind magas húsértékú csontok. A juh/kecske maradványai között alacsony és magas húsértékú csontok is előfordultak. A sertésnek viszont csak fejmaradványai kerültek elő. A 241. házban szarvasmarha-, ló-, juh-/ kecske- és sertéscsontok voltak; az előző házhoz hasonlóan a magasabb és alacsonyabb húsértékú csontok aránya itt is közel azonos. A szarvasmarha- és sertésmaradványok megoszlása hasonló. Alacsony és magasabb húsértékú csontok egyaránt előfordultak, a terminális csontok viszont hiányoztak, ami alapján a maradványok étkezés céljából a házba bevitt maradványok voltak. Erre utalnak a combcsonton (femur) és a lábközépcsonton (metapodium) látható vágások is. Az objektumban talált lócsontok mind a száraz végtag régióhoz tartozó maradványok, amelyek szolgálhattak ugyan étkezési célokat, de nem sok húst adtak. Feltételezhető eszközkészítés céljából való felhasználásuk is, habár egyértelmúen erre utaló nyomok nem figyelhetők meg. Az egyetlen juh-/ kecskemaradvány magas húsértékú lapocka (scapula) töredéke volt. A két kemencéhez kapcsolódó objektum (túztér és munkagödör) szintén tartalmazott háziállat-maradványokat, amelyek túlnyomó része szarvasmarha (adult és juvenilis) teljes testrégiójának maradványa volt (kivéve a terminális régiót).

\section{A feltárt objektumok keltezése - módszerek és kételyek}

A szíjvég alapján meghatározott kronológiai keretek erós érvként vehetők számításba a Csanádpalotán feltárt avar kori telep keltezésénél, hiszen ezek alapján a telepet a 7. század középső harmadában lakták. Ezt a keltezést a 7. század végén megjelenő, lassúkorongolt kerámiák teljes

89 Az állatcsontok vizsgálatát Tóth Anikó (Móra Ferenc Múzeum) végezte. Munkáját ezúton is köszönöm. 

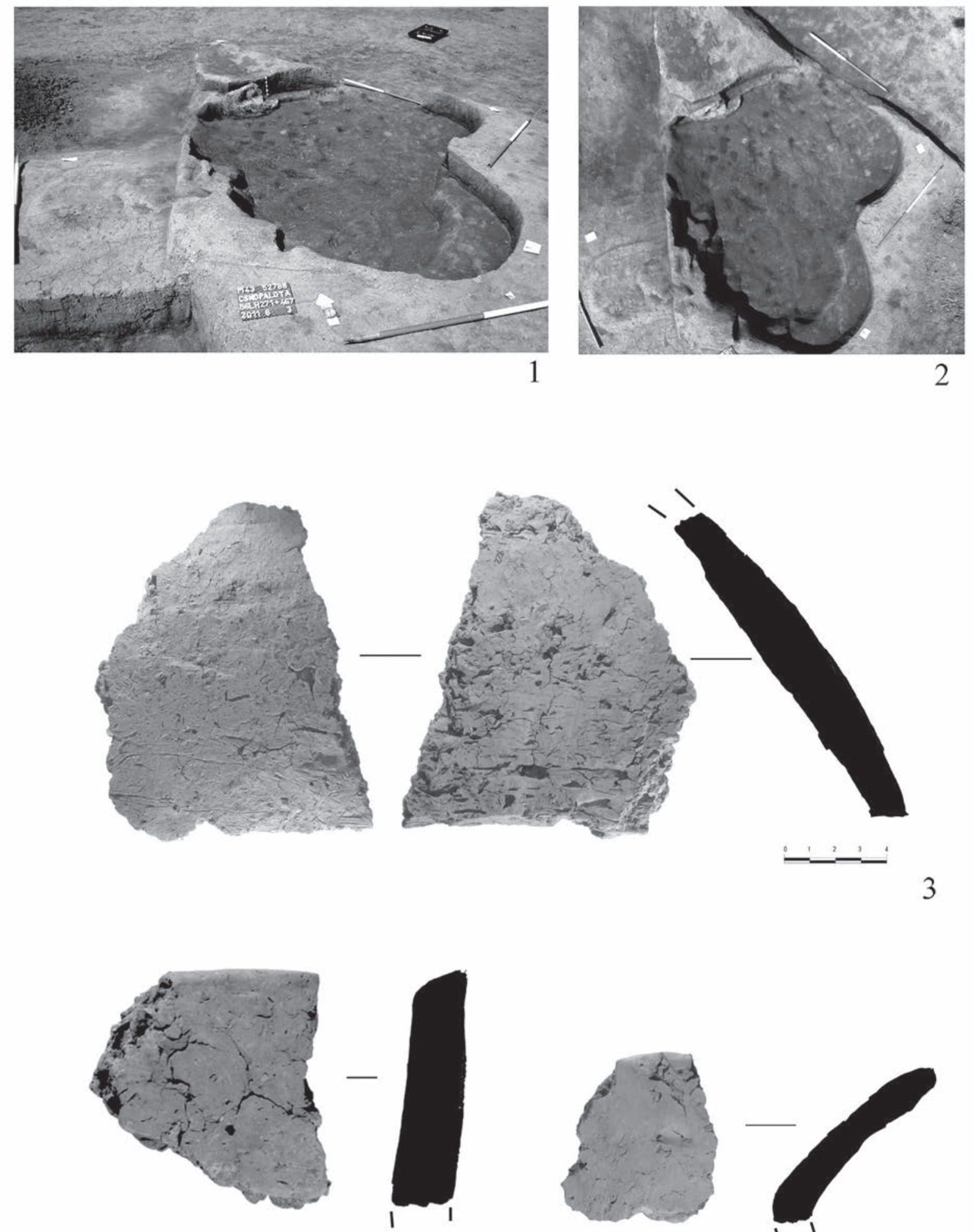

4
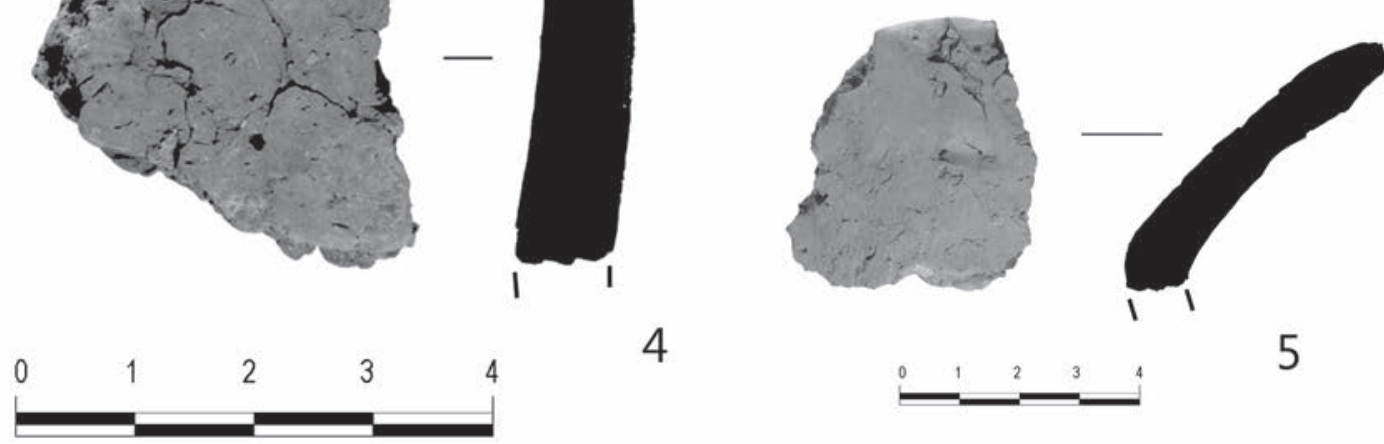

5

5. kép. Csanádpalota-országhatár. 1-2: 144. és 226. kemence; 3-5: edénytöredékek a munkagödörből Abb. 5. Csanádpalota-Staatsgrenze. 1-2: Öfen 144 und 226; 3-5: Gefäßfragmente aus der Arbeitsgrube 
hiányának ténye is megerôsíteni látszik. ${ }^{90}$ További érv lehet a szürke díszkerámia jelenléte a kézzel formált kerámiatöredékek elsörő aránya. A 7-8. században megjelenó, majd a 8-9. században virágkorukat élő, kézzel formált cserépbográcsokra egy perem alapján tudunk következtetni - igaz, némi fenntartással. ${ }^{91}$ Külön figyelmet érdemel a házakban, kemencékben nagy számban előkerült sütőharang-töredék (3. kép 5, 7; 4. kép 4-5; 5. kép 3). Ma már egyre több bizonyíték szól amellett, hogy a sütőharangok nem csak a kései avar korban voltak használatban. Mint a Kárpát-medencébe érkező avar kori nomádok letelepedése nyomán megjelenő, kifejezetten a letelepült életmódot folytató népek háztartására jellemző forma, a kora avar korban a Kárpát-medence legdélebbi, Bizánccal határos területein mutathatók ki leghamarabb. Jelenlétükkel a 7. század közepétól számolhatunk az Alföldön. ${ }^{92}$ A Csanádpalotán használatos példányok e folyamat újabb bizonyítékaiként értékelhetók.

Összegzésképpen a csanádpalotai teleprészletet biztosan 7. századinak tarthatjuk. Mivel nem ismerjük a tarnamérai típusú szíjvég használati, ill. földbe kerülési idejét, ezen belül leginkább a 7. század második felére szúkíthetjük a telep használatának korát. A telep 8. század eleji keltezését semmiképpen nem tartom indokoltnak.

\section{Összegzés: korai telepek - keltezési lehetőségek}

A kora avar kori települések elemzése és keltezése során a telepjelenségek mellett alapvetően a kerámiaanyagra támaszkodhatunk. Mivel azonban egyelőre nem áll rendelkezésünkre a teljes Kárpát-medencére vagy akár csak az Alföld egészére vonatkozó telepkerámia-feldolgozás, az elemzés igen nehézkes. Bár a sírkerámiára vonatkozó megállapítások egyfajta támpontként szolgálnak ebben a munkában, ${ }^{93}$ a különféle kerámiatípusok - különösen a gyorskorongolt szürke kerámia - töredékeinek telepen való felbukkanása számos kérdést vethet fel. Elég arra utalni, hogy egyetlen edénytöredék csupán jelzésértékú lehet a telepen, messzemenő következtetések levonására alkalmatlan. Az Uwe Fiedler által a telepleletek feldolgozása kapcsán felvetett problémákkal a korai telepek felgyújtése és vizsgálata

\footnotetext{
90 VIDA 1999, 110; VIDA 2009, 116.

91 VIDA 1991, 392; HAJNAL 2008, 282.

92 VIDA 2011, 726-728.

93 VIDA 1999.
}

során is szembesülünk. ${ }^{94}$ Ha jobban ismernénk az avar kori telepásatások készítés- és díszítésmód szerint elemzett és szétválasztott edényanyagát, akkor - túl a regionális eltéréseken jobban differenciálni lehetne az egyes kronológiai fázisokat is.$^{95} \mathrm{~A}$ kutatás jelenlegi állapotában az időrendi kereteket csak kismértékben lehet körvonalazni az edénytöredékek tipológiai jegyei alapján.

Ma már elfogadott nézet, hogy a telepkerámiában a korongolt és kézzel formált kerámia mennyisége kronológiafüggő. ${ }^{96}$ Azaz a 7. század végén a teljes avar szállásterületen megjelenő és arányaiban fokozatosan tért nyeró, lassúkorongolt kerámia fokozatos kiegyenlítődést eredményez a Kárpát-medence két régiója között. A 8. századi telepeken már elenyészó a gyorskorongolt kerámia aránya, míg a lassúkorongoltaké fokozatosan nő a korongolatlan edények rovására. ${ }^{97}$ A lassúkorongolt, homokkal soványított, sárgásbarna színú, fésús vonalkötegdíszú, ún. „örménykúti típusú" kerámia megjelenését a 8 . századra, ${ }^{98}$ tömeges elterjedését pedig a 9-10. századra tehetjük. ${ }^{99}$ Ezt a logikát követve adódhat a feltételezés, hogy azokat a telepeket tartsuk biztosan 7. századinak, ahol kizárólagos a durva minőségú, gyengén megmunkált, egyenetlenül kiégetett, szürkés, barnás vagy sárgás színú, korong felhasználása nélkül formált kerámia (Mezőberény). Feltevésünket erősíti a hajdúnánási és a most bemutatott, fémmel is keltezett teleprészlet. A lassúkorongolt kerámia megjelenése mindenképpen "fiatalít" a telepeken. Megjelenésével a 7. század végével már számolni lehet, 100 ahogyan azt a 7-8. század fordulójára keltezett karcagi ház példája sugallja.

A fentiek alapján talán már a 7. század végén megindulhatott az élet a Törökszentmiklós határában feltárt, a 8. század elejére keltezett településen is, ${ }^{101}$ ahonnan csupán két apró, lassúkorongolt fazéktöredék ismert. Szeged-Fertó, Jójárttanya lelóhely kerámiaanyag-összetétele szintén hasonló képet mutat. Ez alapján - felülvizsgálva korábbi álláspontomat - ma már nem tartom kizártnak e telep 7. század végi keltezését. Annál is inkább, mivel a 6 . ház korongolatlan edényén a Mezőberényben megfigyelt, függőlegesen lefutó, fésús vonalkötegdísz is megjelenik a tölcséres

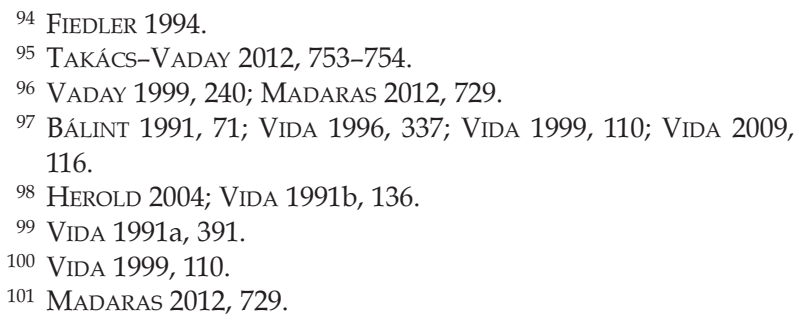


fazékperemek mellett. ${ }^{102}$ Hasonló lehetőség merül fel a Kiskundorozsmáról közölt, a 8. század eleje és a 9. közepe közé keltezett település kapcsán. Itt is döntően kézzel formált a kerámiaanyag, emellett egy lassúkorongolt fazéktöredék, valamint tíz darab szürke és vörös színú, gyorskorongolt kerámiatöredék is felbukkan. ${ }^{103} \mathrm{Ez}$ az összetétel azt sugallja, hogy a településnek lehet egy 7. század végére keltezhető rétege.

Vitatható időrendi besorolása miatt nem került be a fenti lelőhely-katalógusba a JászberényRéti-földek (Jász-Nagykun-Szolnok megye) lelőhelyen feltárt 2. ház. Itt Madaras László 1982-ben egy avar kori teleprészletet tárt fel a Zagyva egykori magaspartján. A hitelesító ásatás során a szelvényben csak egy házat találtak (2. ház). Terepbejárás során foltban azonban további három házhelyet figyeltek meg. A feltárt háznak az akkori felszíntől 1 méter mélyre ásott, dél-északi tájolású négyzetes vermében egy-egy cölöphely, délen lejáratra utaló padka, azzal szemben, az északkeleti sarokban pedig agyagból tapasztott kemence volt. A ház oldalai mentén - a keleti oldalt kivéve - 20-40 cm széles padkát figyeltek meg. A házban kizárólag kézzel formált kerámiát találtak. A peremeket egyszerú ujjbenyomkodás és zsinegszerú bepecsételés, valamint cikcakkmintába rendezett bevagdosás díszítette. ${ }^{104}$ Egyes fazéktöredékek oldalán fésús vonalkötegek láthatók. ${ }^{105}$ Ezek egy része a váll vonalából indítva függólegesen futott le az edény oldalának alsó harmadáig. Sütőharangra, bográcsra, gyorskorongolt szürke, valamint lassúkorongolt kerámiára vonatkozó adatunk nincs. Madaras László - a dunaújvárosi kerámiaanyaggal mutatott rokonsággal érvelve - a 7. század első kétharmadára keltezte az épületet. ${ }^{106} \mathrm{~A}$ keltezés bizonytalanságát azonban jól jelzi, hogy ennek ellentmondva Uwe Fiedler már hivatkozott vitacikkében a 8 . századi telepjelenségek közé sorolta a jászberényi házat. ${ }^{107}$

Látható tehát, hogy a hosszú életú kerámiatípusok miatt a települések élettartamának meghatározása nem egyszerú feladat. A további telepásatások leletei, valamint a feltárt telepkerámia mennyiségének és minőségének százalékos és darabszám szerinti adatsorai, illetve ezek összevetése támpontot nyújthatnak a jövőben. A kronológia pontosítását segíthetik fém-, csont-

\footnotetext{
102 BENEDEK-PÓPITY 2010, 209, 10. kép 3.

103 WILHELM 2010, 213.

104 Madaras 1986, 1-2. tábla.

105 Madaras 1986, 3. tábla.

106 MADARAS 1982, 68.

107 FIEDLER 1994, 318, Abb. 5.
}

vagy más anyagú, a kerámiánál pontosabban keltező tárgyak, valamint az abszolút időkeretet kijelölő természettudományos módszerek.

Az Alföldön feltárt, korainak tartható középavar kori telepek közölt adatai alapján úgy túnik, hogy a letelepült földmúvelö-állattenyésztó életmódot folytató avarság településeit kezdetben laza szerkezet jellemezte. A korabeli vízjárta helyek közelében 6-12 $\mathrm{m}^{2}$ alapterületú, négyzetes vagy téglalap alaprajzú, félig földbe mélyített, néha agyagból és kőből épített kemencével ellátott házakat emeltek. Tájolásuk az adott terepviszonyokhoz alkalmazkodott. A házak körül árkok is húzódhattak (Kiskunfélegyháza, Hajdúnánás). A hiteles, átfogó kép megrajzolásához egyelőre azonban túl kevés adat áll rendelkezésünkre, kis felületről. A Tiszántúlon és a DunaTisza közén az újonnan megjelenő avar telepek mellett számolnunk kell a tovább élő gepidák telepeivel is. A korábban feltárt, de közöletlen telepek közzététele és elemzése, valamint a legújabb ásatások adatainak bevonása, a regionális léptékú kutatások előrelépést hozhatnak a 7. századi telepek pontosabb kronológiájának és településképének körvonalazásában.

\section{KATALÓGUS}

\section{Csanádpalota-országhatár lelőhely avar telepobjektumai és leletei}

\section{6+144. kemencebokor (5. kép 1-2)}

Részei: SNR 271: nyugati sütőfelület, SNR 466-467: megújított munkagödrök, SNR 465: északi sütőfelület.

Munkagödör h.: 190 cm; sz.: 164-200 cm; m.: 20-32 cm. Munkagödör tájolása: É-D, K-Ny. Északi sütőfelület h.: 115 cm; sz.: 100 cm; v.: 4 cm. Nyugati sütőfelület h.: 108 cm; sz.: $63 \mathrm{~cm}$; v.: $5 \mathrm{~cm}$.

Kemencebokor egy nagyobb munkagödörrel és hozzá kapcsolódó két kemencével. Az előtérgödör ovális foltján nem lehetett megfigyelni megújításra utaló nyomot, ami nem zárja ki annak lehetőségét, hogy az északi és nyugati kemence egy időben múködött egymás mellett. Az előtérgödör legszélesebb része az északi (SNR 465) kemence előtt található. Itt, a kemence szája előtt $55 \mathrm{~cm}$ hosszú, $12 \mathrm{~cm}$ széles és $30 \mathrm{~cm}$ magas sárga agyagfalazatot (!) figyeltünk meg. Ebből az agyagrétegből készült a sütőfelület. Az előtérgödör függőleges oldalfalú, alja DK felé lejtett. A munkagödör alja és az SNR 271 kemence sütőfelületének alja között $34 \mathrm{~cm}$ volt a szintkülönbség. Maga a nyugati sütőfelület ovális alakú, erősen átégett és teljesen vízszintes volt. Szájrésze nehezen követhető, közel $46 \mathrm{~cm}$ széles. A munkagödör északi oldalán található SNR 465 kemence sütőfelülete szintén ovális alakú, de kissé lejtett a munkagödör irányában. A szájrész $50 \mathrm{~cm}$ széles. A sütőfelület és a munkagödör (SNR 466-467) szintkülönbsége $27 \mathrm{~cm}$. A sütőfelület sérült, nem teljes. 
Állatjárások bolygatták, a szájrész előtt is hiányos volt. Kerámiaréteg egyik sütőfelületben sem került elő.

A munkagödör leletei:

1. Sütőharang peremtöredéke. Kívül barna, belül pirosas színú, kerámiazúzalékkal és némi szerves anyaggal soványított, kézzel formált (5. kép 3). A perem ferdén levágott szélú. H.: 13,2 cm, v.: 1,5 cm, pátm.: $\sim 40 \mathrm{~cm}$. MFM ltsz.: 2013.1.922.

2. Fazék peremtöredéke. Barna színú, kerámiazúzalékkal soványított, kézzel formált, tölcséresen kihajló, $4 \mathrm{~cm}$ magasra ívelődő, lekerekített szélú (5. kép 5). H.: 4,5 cm, v.: 1 cm. MFM ltsz.: 2013.1.921.

3. Edény (bogrács?) peremtöredéke. Barna színú, kerámiazúzalékkal és némi szerves anyaggal soványított, kézzel formált (5. kép 4). Az egyenes állású perem az edény belső oldala felé ferdén lecsapott szélú. H.: 3,8 cm, v.: $0,9 \mathrm{~cm}$. MFM ltsz.: 2013.1.919.

4. Edény peremtöredéke. Barna színú, kerámiazúzalékkal és némi szerves anyaggal soványított, kézzel formált. A perem vaskos, közel egyenes állású, széle lekerekített. H.: 5,6 cm, v.: 1,3 cm. MFM 1tsz.: 2013.1.919.

5. Edény peremtöredéke. Barna színú, kerámiazúzalékkal soványított, kézzel formált. A perem egyenes állású, széle lekerekített. H.: $4,5 \mathrm{~cm}$, v.: $1 \mathrm{~cm}$. MFM ltsz.: 2013.1.920.

6. Edények oldaltöredékei. Barna színú, kerámiazúzalékkal és némi szerves anyaggal soványított, kézzel formált. H.: 4-5,6 cm, v.: 1-1,3 cm. MFM ltsz.: 2013.1.922-923.

\section{1. ház (2. kép 4; 3. kép 1)}

Részei: SNR 483: házverem, SNR 505: cölöphely, SNR 506: cölöphely.

Méretek, tájolás: h.: $290 \mathrm{~cm}$, sz.: $265 \mathrm{~cm}, \mathrm{~m} .: 50 \mathrm{~cm}$. T.: ÉNy-DK.

Az épület csaknem szabályos, közel négyzetes alakú gödrének foltja $66 \mathrm{~cm}$ mélyen rajzolódott ki. Azaz a közel négyzetes házverem lekerekített sarkú gödre közel 110120 cm-re mélyedt a mai felszín alá. A házverem függőleges vagy erősen rézsús oldalú. A házban kemence, túzhely nem volt. Csupán 1-2 cm vastag, keményre letaposott réteget figyeltünk meg a lapos, kissé egyenetlen padlószinten. Ebbe a ház északnyugati és délkeleti oldalai mentén, az oldalfalak közepén egy-egy cölöplyuk mélyedt. Mindkét beásás széles és sekély. Szerkezetük kissé eltér, a délkeleti oldalon található cölöphelyet ugyanis a fal oldalsíkjából enyhén kiugró megoldással ásták meg. A házverem közepéból bronzveret, kézzel formált kerámia, kő, patics és állatcsont került elő. A cölöphelyek leletet nem tartalmaztak.

A házverem leletei:

1. Edény kúpos nyaktöredéke. Barna színú, homokkal és kerámiazúzalékkal soványított, kézzel formált (3. kép 6). H.: 10,3 cm, v.: 0,7 cm. MFM ltsz.: 2013.1.949.

2. Sütőharang oldaltöredéke. Kívül szürkésbarna, belül vörösesbarna színú, kerámiazúzalékkal soványított, kézzel formált, durva felületú, vastag falú (3. kép 5). H.: 8,9 cm, v.: 1,7 cm. MFM ltsz.: 2013.1.950.

3. Sütőharang kisebb, félbetört oldaltöredéke. Barna színú, kerámiazúzalékkal soványított, kézzel formált. H.: 4,9 cm, v.: 1,2 cm. MFM ltsz.: 2013.1.953.
4. Sütóharang íves fültöredéke. Fekete foltos barna színú, kerámiazúzalékkal soványított, kézzel formált, vastag falú. Átmetszete lapított, trapézos. Pereme lapított. Sz.: 5 cm, m.: 4 cm. MFM ltsz.: 2013.1.963.

5. Edény oldaltöredékei (8 db). Világosbarna színú, koromfoltos, kerámiazúzalékkal soványított, kézzel formált. H.: 2,7-8,4 cm, v.: 0,9-1,1 cm. MFM ltsz.: 2013.1.951.

6. Edény oldaltöredékei. Szürkésbarna színú (4db), kívül téglavörös, belül világosbarna színú $(1 \mathrm{db})$, kívül tojásfehér, belül fekete színú (1 db), kívül szürkésbarna, belül fekete és világosbarna színú (6 db), kerámiazúzalékkal soványított, kézzel formált. H.: 2,9-9,1 cm, v.: 0,81,3 cm. MFM ltsz.: 2013.1.956-960.

7. Edény oldal- és aljtöredéke. Kívül vörösesbarna, belül szürke színú, kerámiazúzalékkal soványított, kézzel formált. Az alj enyhén profilált, kerek formájú, lapos. H.: 8,9 cm, v.: 0,9 cm, fátm.: $15 \mathrm{~cm}$. MFM ltsz.: 2013.1.961.

8. Edény aljtöredéke. Kívül-belül barna színú, kerámiazúzalékkal soványított, kézzel formált, vastag falú, nagyméretú. Az alj formája kerek, lapos, vastag falú. H.: 12,5 cm, v.: 1,5 cm, fátm.: 15 cm. MFM ltsz.: 2013.1.962.

9. Edény lapos aljtöredéke. Kívül világosbarna, belül szürkésbarna színú, homokkal és kerámiazúzalékkal soványított, kézzel formált. H.: 4,2 cm, v.: $1 \mathrm{~cm}$. MFM ltsz.: 2013.1.952.

10. Edény lapos aljtöredéke. Szürkésbarna színú, kerámiazúzalékkal soványított, kézzel formált. H.: $6,3 \mathrm{~cm}$, fátm.: $14 \mathrm{~cm}$, v.: 1,7 cm. MFM ltsz.: 2013.1.964.

11. Fenőkövek töredékei (5 db). Szürke színú kő (homokkó?). Átmetszetük valószínúleg téglalap alakú lehetett. Oldalaik simára csiszoltak. H.: 3,3-6,2 cm, v.: 2,7-3,1 cm, s.: 185 g. MFM ltsz.: 2013.1.4487.

12. Kődarab. Fekete színú. H.: 5,7 cm, s.: 65 g. MFM 1tsz.: 2013.1.4488.

13. Kődarab (csillámpala?). Sötétszürke színú. H.: 7,2 cm, s.: 70 g. MFM ltsz.: 2013.1.4489.

14. Paticsok és tapasztás töredékei (4 db). Vörös színú, amorf formájú, növényi lenyomatos, koromfoltos. S.: 40 g. MFM ltsz.: 2013.1.4624.

15. Tarnaméra-típusú nagyszijvég (3. kép 2). Bronzlemezből préselt. Formája lekerekített végú téglalap, széle három oldalról peremesen visszahajló. Felületén pontsorral övezett geometrikus díszek, középen koncentrikus körökben egyenlő szárú kereszt. A szíjvég egyenes felső végének közepén kerek formájú, rögzítést szolgáló áttörés (átm.: 0,3 cm). H.: 5,4 cm, sz.: 2,4 cm, szegecs furatának átm.: 0,3 cm. MFM ltsz.: 2013.1.4809.

16. Orsókarika. Szürke szarmata edényoldalból faragott ép röpsúly (3. kép 8). Ovális, törésfelületének egyik fele simára csiszolt. Vaskos, hombárszerú edény oldalából készült. Középen 0,5 cm átmérőjú, egyik oldalán tölcséresen kiszélesedő furat található. Állaga: $1 \mathrm{db}$. Méretek: h.: 6,5 cm, sz.: 5,5 cm, v.: 1 cm. S.: 70 g. MFM ltsz.: 2013.1 946.

17. Szürke díszkerámia töredékei. Soványítás nélkül, gyorskorongon készült. Külső oldalán a felületet lapos késsel faragták, simították el. A belső oldalon korongnyomok vannak (3. kép 3-4). Állaga: 2 db. Méretek: h.: 4,2-6,6 cm; v.: 0,5-0,7 cm. S.: 32 g. MFM 1tsz.: 2013.1.947. 
230. ház (2. kép 3, 5; 4. kép 1)

Részei: SNR 459: házverem, SNR 474: cölöphely, SNR 495: cölöphely.

Méretek, tájolás: h.: $324 \mathrm{~cm}$, sz.: $242 \mathrm{~cm}, \mathrm{~m} .: 43 \mathrm{~cm}$. T.: K-Ny.

Szabályos téglalap alakú, lekerekített sarkú gödörház, amely kissé szabálytalan, agyagos-humuszos foltként jelentkezett. Oldalai meredeken estek a lapos padlószint irányában. A ház keleti harmadában ezen a szinten keményre taposott, 1-2 cm vastag réteget figyeltünk meg. A rövidebbik keleti és nyugati oldalak közepén egy-egy cölöphely volt. A betöltésből kézzel formált kerámia, patics és állatcsont került elő. Anyaga részben keveredett a később ráásott, szabadban álló kemence tűzterének (SNR 490) betöltésében található avar leletekkel. A cölöphelyek leletet nem tartalmaztak.

A házverem leletanyaga (SNR 459):

1. Edények oldaltöredékei egy lapos aljtöredékkel (5 db). Kívül és belül fekete foltos barna színú, homokkal és kerámiazúzalékkal soványított, vastag falú, kézzel formált. H.: 3,7-10,2 cm, v.: 0,9-1,6 cm. MFM 1tsz.: 2013.1.930.

2. Edény aljtöredéke. Világosbarna színú, kerámiazúzalékkal soványított, vastag falú, kézzel formált. Az alj formája kerek, lapos. H.: $6,1 \mathrm{~cm}$, v.: $1,4 \mathrm{~cm}$, fátm.: $15 \mathrm{~cm}$. MFM ltsz.: 2013.1.931.

3. Edények perem-és oldaltöredékei (2 db). Barna színú, kerámiazúzalékkal soványított, kézzel formált, vastag falú. Az egyik töredék sütőharang peremtöredéke. A vöröses színú belső oldal durván, a kívül világosbarna színú oldal jobban simított. A perem szögletesen simított. H.: 6,4-8,8 cm, v.: 1,2-1,6 cm. MFM ltsz.: 2013.1.932.

4. Paticstöredékek (2 db). Vörös színú, amorf formájú, növényi lenyomatos. MFM ltsz.: 2013.1.4620.

242. kemence (3. kép 3; 4. kép 2)

Részei: SNR 490: kemence munkagödör, SNR 458: kemence túztér, SNR 504: sütőfelület.

Méretek, tájolás: h.: 380 cm, sz.: 140-170 cm, m.: 36-40 cm. T.: É-D.

A kemence vörös színú, ovális gyưrúként jelentkező foltja és a hozzá tartozó előtérgödör kormos, paticsos foltja a mai felszín alatt $60-66 \mathrm{~cm}$ mélyen rajzolódott ki a 230. ház keleti felében. A ház és a kemence betöltése eltérő színú foltként jelentkezett. A ház vermét kitöltő barna talaj alapszínéhez képest a kemence előterének sötétebb tónusú, kormosabb, ovális foltja felülrétegezte a ház foltját. A kemence szájának vonalában már a foltban feltúnt egy sárga agyagos, a talajviszonyokhoz mérten oda nem illő sáv, amely a későbbi rábontáskor masszív, sárga agyagból rakott, $60 \mathrm{~cm}$ hosszú, $10 \mathrm{~cm}$ széles és $20 \mathrm{~cm}$ magas tapasztásnak bizonyult. A tapasztás egyfajta épített gátként húzódott keresztben a kemence túztere és az előtér munkagödre között. A túztér felőli oldala át volt égve. A kemence előterének alja nem mélyedt le a korábbi ház padlószintjének mélységéig, annál $5 \mathrm{~cm}$-rel magasabban végződött. Ez a kemence szájrésze előtt jól követhetően megmaradt. Az előtérgödör szív alakú lehetett, északon $140 \mathrm{~cm}$-re vállasan kiszélesedő. A déli oldalon csaknem a házverem oldalfaláig érhetett a széle. A hozzá északról kapcsolódó, ovális túztér nagy részét a humuszrétegbe vájták, így az a szántás során elpusztult. A ke- mence boltozatának fala a szántáshatár közelsége miatt alig $10 \mathrm{~cm}$ magasan maradt meg. A $2-3 \mathrm{~cm}$ vastagon átégett, teljesen lapos, ovális alakú, $110 \mathrm{~cm}$ hosszú és 160 $\mathrm{cm}$ széles sütőfelület feletti túztér rétege gazdag volt leletekben. A sütőfelületbe nem tapasztottak edény- vagy állatcsonttöredékeket. Mivel az objektumhatárok pontos megállapítása az érintkezési pontokon nem volt egyértelmú, a bontás során a ház és a kemence előterének anyaga részben keveredett egymással.

A tüztér leletei (SNR 458):

1. Lapos tál teljes profilú perem-, oldal- és aljtöredéke (4. kép 2). Sötétbarna színú, kerámiazúzalékkal soványított, kézzel formált, ferdén kihajló falú. A perem lekerekített, az oldalfal egyenesen, a lapos alj irányában vastagodó. Az alj formája kerek és lapos. Pátm.: $30 \mathrm{~cm}$, fátm.: 25 cm, m.: 10,7 cm. Becsült úrmérték: 6,8 liter. MFM ltsz.: 2013.1.965.

2. Edény perem- és oldaltöredéke (4. kép 3). Sötétbarna színú, fekete foltos, kerámiazúzalékkal soványított, kézzel formált. Pereme alacsony, ívelten kihajló, lekerekített szélú. A nyak és a váll tagolatlan, kúpos. H.: 11 cm, v.: 0,8 cm, pátm.: $15 \mathrm{~cm}$. MFM ltsz.: 2013.1.966.

3. Edény perem-és nyaktöredéke (4. kép 6). Barna színú, kerámiazúzalékkal soványított, kézzel formált. A tölcséresen kihajló perem lekerekített szélú. H.: 6,3 cm, v.: 0,9 cm, pátm.: $15 \mathrm{~cm}$. MFM ltsz.: 2013.1.967.

4. Sütöharang belső részének oldaltöredéke. Világosbarna színú, kerámiazúzalékkal soványított, kézzel formált, durván simított felületú. H.: 4,7 cm, v.: 0,9 cm. MFM ltsz.: 2013.1.968.

5. Világosbarna (1 db), vörös foltos szürke (1 db), kívül sötétbarna, belül világosbarna és fekete színú $(2 \mathrm{db})$, kerámiazúzalékkal soványított, kézzel formált, durva felületú edények oldaltöredékei. H.: 3,7-4,7 cm, v.: 0,8-0,9 cm. MFM ltsz.: 2013.1.967-970.

6. Edények oldal-és aljtöredékei. Kívül barna, belül fekete $(1 \mathrm{db})$, világosbarna színú (1 db), kerámiazúzalékkal soványított, kézzel formált, vastag falú. Az alj formája kerek, lapos. H.: 5,2-7,1 cm, v.: 1,4-1,7 cm. MFM ltsz.: 2013.1.971-972.

7. Paticsdarabok (3 db). Vörös színú, amorf formájú, növényi lenyomatos, koromfoltos. MFM ltsz.: 2013.1.4625.

A munkagödör és a ház kevert leletei (SNR 490-459):

1. Edény oldaltöredéke. Kívül-belül barna színú, homokkal és kerámiazúzalékkal soványított, kézzel formált, vastag falú. H.: 3,5 cm, v.: 1,4 cm. MFM ltsz.: 2013.1.975.

2. Edény perem- és nyaktöredéke (4. kép 7). Fekete foltos barna színú, durva szemú kerámiazúzalékkal soványított, kézzel formált. Pereme alacsony, tölcséresen kihajló, lekerekített végú. Nyakvonala és vállvonala ívelt. H.: 10,2 cm, v.: 0,7 cm. MFM ltsz.: 2013.1.976.

3. Tál egyenes peremtöredéke. Kívül sötétbarna, belül világosbarna színú, kerámiazúzalékkal soványított, kézzel formált, tölcséresen kihajló falú, lapos. A peremszél lekerekített (a 2013.1.965. sz. tálhoz tartozik). H.: 4,3 cm, v.: $1 \mathrm{~cm}$. MFM ltsz.: 2013.1.977.

4. Edény perem- és oldaltöredékei (2 db). Szürkésbarna színú, kerámiazúzalékkal soványított, kézzel formált, A peremszél kihajló, lekerekített végú. $H .:$ 3,8-4,1 cm, v.: 0,9-1 cm. MFM ltsz.: 2013.1.978. 
5. Sütöharangok perem- és oldaltöredékei (8 db). Kívül sötétbarna, belül világos vörösesbarna színú, kerámiazúzalékkal soványított, kézzel formált, vastag falú. Pereme egyenesre levágott végú (4. kép 4-5). H.: 4,6-10,7 cm, v.: 1,3-2,2 cm, pátm.: $\sim 30 \mathrm{~cm}$. MFM ltsz.: 2013.1.979.

6. Vaskos falú sütöharang fültöredékei (2 db). Barna színú, kerámiazúzalékkal soványított, kézzel formált, vastag falú, ovális átmetszetú. A perem kihajló. H.: 4,1-4,6cm, v.: 1,4-1,6 cm. MFM 1tsz.: 2013.1.980.

7. Edények oldaltöredékei. Kívül-belül barnás-fekete színú (3 db), homokkal soványított, kézzel formált. H.: 3,6-4,6 cm, v.: 0,8-1 cm. MFM ltsz.: 2013.1.981.

8. Edények és egy sütöharang oldaltöredékei. Szürkésbarna színú (3 db), sötétbarna ( $8 \mathrm{db})$, kívül szürkésbarna, belül sötétbarna (3 db), kívül vörösesbarna, belül sötétbarna és fekete színú (3 db), kerámiazúzalékkal soványított, kézzel formált, valamint egy belül vöröses, kívül barna színú (sütóharang). H.: 2,9-7,9 cm, v.: 0,6-1,4 cm. MFM 1tsz.: 2013.1.982-984.

9. Edények oldal- és aljtöredékei (7 db). Világosbarna színú, durva szemú kerámiazúzalékkal soványított, kézzel formált. Az alj lapos. H.: 2,7-7,6 cm, v.: 0,8-1,7 cm. MFM ltsz.: 2013.1.985.

10. Edények oldal- és aljtöredékei ( $2 \mathrm{db})$. Világosbarna és fekete színú, kerámiazúzalékkal soványított, kézzel formált, vastag falú, belül durván, kívül jobban eldolgozott felületû. H.: 9,7-10,3 cm, v.: 1,1-1,3 cm, fátm.: $12 \mathrm{~cm}$. MFM ltsz.: 2013.1.987-988.

11. Edény oldal-és aljtöredéke. Világosbarna színú, kerámiazúzalékkal soványított, kézzel formált, vastag falú, durva felületú. Az alj enyhén kiszélesedő. Fenék átm.: 12 cm, v.: 1,2 cm. MFM 1tsz.: 2013.1.989.

12. Edény oldal-és aljtöredéke. Világosbarna színú, homokkal soványított, kézzel formált. Az alj kerek formájú, lapos. H.: 4,2 cm, v.: 0,9 cm. MFM ltsz.: 2013.1.990.

13. Patics és tapasztás töredékei (8 db). Vörös színú, amorf formájú, koromfoltos. S.: 155 g. MFM ltsz:: 2013.1.4626.

\section{SNR 255 újkori árok avar leletei}

A 242. kemencétól 10 méterre délnyugatra feltárt, L alakú újkori kerítóárokban négy avar kori kerámiatöredék feküdt újkori leletek társaságában.

1. Sütőharang peremtöredéke. Szürke foltos barna színú, kerámiazúzalékkal és némi szerves anyaggal soványított. A perem széle laposra nyomott. H.: $5,5 \mathrm{~cm}$, v.: $1,7 \mathrm{~cm}$. MFM ltsz.: 2013.1.4213.

2. Edények oldaltöredékei. Kívül barna, belül szürke színú, kerámiazúzalékkal és némi szerves anyaggal soványított. H.: 3,3-5,5 cm, v.: 1 cm. MFM ltsz.: 2013.1.42114212.

\section{IRODALOM}

BÁLINT, CSANÁD

1991 Die spätawarenzeitlichen Siedlungen von Eperjes (Kom. Csongrád). Varia Archaeologica Hungarica 4. Budapest.

BALOGH CSILLA

2002 Kiskunfélegyháza, Pap-dúlő. In: Kisfaludi J. (szerk.): Régészeti Kutatások Magyarországon 2001. (Archaeological Investigations in Hungary 2001). Budapest, 227-228.

BENEDEK ANDRÁs-PÓPITY DÁNIEL

2010 Késő avar kori településrészlet Szeged-Fertő, Jójárt-tanya területéről (Spätawarenzeitliches Siedlungsfragment in Szeged-Fertő, Jójárt-tanya). In: Lőrinczy G. (szerk.): Pusztaszertől Algyőig. Régészeti lelőhelyek és leletek egy gázvezeték nyomvonalának Csongrád megyei szakaszán. Móra Ferenc Múzeum Évkönyve - Monumenta Archaeologica (Szeged) 2, 193-209.

BÓNA ISTVÁN

1973 VII. századi avar települések és Árpád-kori magyar falu Dunaújvárosban (Awarische Siedlungen aus dem 7. Jahrhundert und ein ungarisches Dorf aus der Arpadenzeit - 11.-13. Jh. - in Dunaújváros). Fontes Archaeologica Hungarica 4. Budapest.

1984 A népvándorláskor és a korai középkor története Magyarországon. In: Bartha A. (szerk.): Magyarország története. Előzmények és magyar történet 1242-ig. I. Budapest, 265-373.

CSALlÁny DEZsó

1940 Korai avar edények Magyarországon. Dolgozatok (Szeged) 16, 118-133. ERDÉLYI ISTVÁN

1958 A jánoshidai avar temető. Régészeti Füzetek (Budapest) Ser. II-1.

FETTICH NÁNDOR

1926 Az avarkori múipar Magyarországon. Das awarenzeitliche Kunstgewerbe in Ungarn. Archaeologica

FIEDLER, UWE Hungarica 1. Budapest.

1994 Zur Datierung der Siedlungen der Awaren und Ungarn nach der Landnahme. Ein Beitrag zur FODOR ISTVÁN Zuordnung der Siedlung von Eperjes. Zeitschrift für Archaeologie (Berlin) 28, 307-352.

2006 A magyar gazdálkodás változásai a 10. században. In: Fodor I. (szerk.): A fénylő középkor. Tanulmányok Kovalovszki Júlia tiszteletére. Budapest-Békéscsaba, 13-33. 
2012 Avar kori lakóházak Hajdúnánáson (Awarenzeitliche Grubenhäuser in Hajdúnánás). In: Vida T. (szerk./ ed.): Thesaurus Avarorum. Régészeti tanulmányok Garam Éva tiszteletére. Archaeological Studies in Honour of Éva Garam. Budapest, 709-720.

FODOR LÁSZLÓ-VIDA TIVADAR

2013 Kora avar kori temetőrészlet Szihalom-Budaszögről (An Early Avar period cemetery at SzihalomBudaszög). Archaeologiai Értesítő (Budapest) 138, 157-173.

FÜLÖP GYULA

1981 Avarkori kemence Kálóz-Nagyhörcsökön (Backofen aus der Awarenzeit in Kálóz-Nagyhörcsök). Alba Regia (Székesfehérvár) 19, 251-258.

GARAM ÉVA

1981 VIII-IX. századi telepnyom Tiszafüred határában (Siedlungsspur aus dem 8.-9. Jh. in der Gemarkung von Tiszafüred). Communicationes Archaeologicae Hungariae (Budapest) 137-147.

1995 Das awarenzeitliche Gräberfeld von Tiszafüred. In: Kiss, A.-Garam, É. (eds): Cemeteries of the Avar Period (567-829) in Hungary 3. Budapest.

2001 Funde byzantinischer Herkunft in der Awarenzeit vom Ende des 6. bis zum Ende des 7. Jahrhunderts. Monumenta Avarorum Archaeologica 5. Budapest.

GULYÁS GYÖNGYI

2009 Szeged-Tápé, 86. sz. kútkörzet. In: Kisfaludi J. (szerk.): Régészeti Kutatások Magyarországon 2008 (Archaeological Investigations in Hungary 2008). Budapest, 286-287.

HAJNAL ZSUZSANNA

2003 Mécsesek a kölked-feketekapui avar telepről (Öllampen aus der Awarensiedlung Kölked-Feketekapu). Archaeologiai Értesítő (Budapest) 128, 177-209.

2005 Késő antik jellegú kerámia a kölked-feketekapui avar kori telepről (Keramik spätantiken Charekters aus der awarenzeitlichen Siedlung Kölked-Feketekapu). Communicationes Archaeologicae Hungariae (Budapest) 437-480.

2008 Adatok az avar kori cserépbográcsok és sütőharangok időrendjéhez (Angaben zur Chronologie der awarenzeitlichen Tonkessel und Backglocken). Communicationes Archaeologicae Hungariae (Budapest) 267-293.

2009 Házak a kölked-feketekapui avar kori telepen (Häuser in der awarenzeitlichen Siedlung KölkedFeketekapu). Archaeologiai Értesító (Budapest) 134, 91-116.

2013 Kora avar kori pecsételt díszú kerámia Kölkeden (Frühawarenzeitliche stempelverzierte Keramik in Kölked). Archaeologiai Értesítő (Budapest) 138, 175-211.

HEROLD, HAJNALKA

2004 Die frühmittelalterlichen Siedlungen von Örménykút 54. Varia Archaeologica Hungarica 14. Budapest.

HOREDT, KURT

1979 Moreşti. Grabungen in einer vor- und frühgeschichtlichen Siedlung in Siebenbürgen. Bonn.

IVANIŠEVIĆ, VUJADIN-BUGARSKI, IVAN

2008 Western Banat during the Great Migration Period. In: The Turbulent Epoch. New materials from the Late Roman Period and the Migration Period. Lublin, 39-61.

KisS, ATTILA

1979 Das Gräberfeld und die Siedlung der awarenzeitlichen germanischen Bevölkerung von Kölked. Folia Archaeologica (Budapest) 30, 185-192.

KOVALOVSZKI JÚLIA

1975 Előzetes jelentés a dobozi Árpád-kori falufeltárásról 1962-1974 (Vorbericht über die Ausgrabungen im arpadenzeitlichen Dorf bei Doboz). Archaeologiai Értesítő (Budapest) 102, 104-223.

LÓRINCZY GÁBOR

1998 Kelet-európai népesség a 6-7. századi Kárpát-medencében (Osteuropäische Steppenbevölkerung im 6. und 7. Jahrhundert im Karpatenbecken). Móra Ferenc Múzeum Évkönyve - Studia Archaeologica (Szeged) 4, 343-372.

MAdARAS LÁSZLó

1982 Jászberény-Réti földek (Szolnok megye). Régészeti Füzetek (Budapest) Ser. I. No. 35, 68.

1986 Az avar kori településkutatás néhány újabb eredménye az Alföld központi területein (New results in setting-research of the Avar period in the centre of the Great Hungarian Plan). In: Novák L.-Selmeczi L. (szerk.): Falvak, mezővárosok az Alföldön. Arany János Múzeum Közleményei (Nagykőrös) 4, 33-65.

2000 Avar kori településrészlet Szentes határában. Leletmentés a 451. sz. út Szentest elkerülő szakaszán (Ein awarenzeitliches Siedlungsdetail in der Gemarkung von Szentes. Rettungsgrabung auf dem Umleitungsweg 451 bei Szentes). Móra Ferenc Múzeum Évkönyve - Studia Archaeologica (Szeged) 6, 237-262.

2012 Avar kori település Törökszentmiklós határában (Die awarenzeitliche Siedlung in der Gemarkung von Törökszentmiklós) In: Vida T. (szerk.): Thesaurus Avarorum. Régészeti tanulmányok Garam Éva tiszteletére (Archaeological Studies in Honour of Éva Garam). Budapest, 721-731. 
MRT 8

1989 Jankovich B. D.-Makkay J.-Szőke B. M.: A szarvasi járás. Magyarország Régészeti Topográfiája 8. Békés megye régészeti topográfiája. Torma I. (szerk.). Budapest.

MRT 10

1998 Jankovich B. D.-Medgyesi P.-Nikolin E.-Szatmári I.-Torma I.: Békés és Békéscsaba környéke. Magyarország Régészeti Topográfiája 10. Békés megye régészeti topográfiája. Torma I. (szerk.). Budapest.

ROSNER GYULA

1979 Avar kerámiaközpont Szekszárd környékén (Keramisches Zentrum der Awaren in der Umgebung von Szekszárd). Szekszárdi Béri Balogh Ádám Múzeum Évkönyve 8/9, 97-108.

Rózsa Zoltán-T. Biró Katalin-Tugya BeÁta

2011 Avar kori teleprészlet Orosháza határában (OH. 13. lelőhely - Békés megye). In.: Kolozsi B.-Szilágyi K. A. (szerk.): Sötét idők falvai. 8-11. századi települések a Kárpát-medencében. Debrecen, 93-146.

SALAMON, ÁGNES-SEBESTYÉN, KÁROLY

1995 The Szeged-Kundomb Cemetery. In: Madaras L. (Hrsg.): Das awarische Corpus. Beihefte IV. Debrecen-

ŠALKOVSKÝ, PETER Budapest.

2011 Das frühmittelalterliche Dorf im Karpatenbecken. In: Kolozsi B.-Szilágyi K. A. (szerk.): Sötét idők falvai. SOMOGYVÁRI ÁGNES 8-11. századi települések a Kárpát-medencében. Debrecen, 419-450.

2009 Nemesnádudvar, Sziget-Kaszáló. In: Kisfaludi J. (szerk.): Régészeti Kutatások Magyarországon 2008 SZABÓ JÁNOS GYŐZŐ (Archaeological Investigations in Hungary 2008). Budapest, 293.

1965 Az egri múzeum avarkori emlékanyaga. I. Kora avarkori sírleletek Tarnaméráról (Der awarenzeitliche Fundbestand des Museums von Eger. I. Frühawarenzeitliche Grabfunde aus Tarnaméra). Egri Múzeum Évkönyve (Eger) 3, 29-53.

SZATMÁRI SAROLTA

1984 Avar temető- és telepásatás Tatabánya-Alsógalla mellett (Awarische Gräberfeld- und Siedlungsausgrabung bei Tatabánya-Alsógalla). Szolnok Megyei Múzeumok Évkönyve (Szolnok) (1982-83) 67-79.

SZENTPÉTERI, JÓZSEF (Hrsg.)

2002 Archäologische Denkmäler der Awarenzeit in Mitteleuropa. Varia Archaeologica Hungarica 13/2. Budapest.

SZŐKE BÉLA MiKLÓS

1992 7. és 9. századi településmaradványok Nagykanizsán (Siedlungsreste aus dem 7. und 9. Jh. in Nagykanizsa, SW-Ungarn). Zalai Múzeum (Zalaegerszeg) 4, 129-167.

TAKÁCS, MiKLÓS

2002 Der Hausbau in Ungarn vom 2. bis zum 13. Jahrhundert n. Chr. - Ein Zeitalter einheitlicher Grubenhäuser? (The houses of village-like settlements in Hungary of the $2^{\text {nd }}-13^{\text {th }}$ centuries A.D. A period of uniform huts with sunken floors?). In: Klapště, J. (ed.): The rural house from the migration period to the oldest still standig buildings. Ruralia IV. Bad Bederkesa 2001. Památky Archeologické Supplementum 15. Prague, 272-290.

TAKÁCS MIKLÓS-VADAY ANDREA

2012 A Kompolt-Kistéri-tanyai kézzel formált és utánkorongolt cserépbográcsok (Die handgeformten und nachgedrehten Tonkessel von Kompolt-Kistéri-tanya). In: Vida T. (szerk.): Thesaurus Avarorum. Régészeti tanulmányok Garam Éva tiszteletére (Archaeological Studies in Honour of Éva Garam). Budapest, 743-769.

TÖRÖK GYULA

1984 Avarkori temető Csengelén - Szeged-Csengele-Fekete halom (Awarenzeitliches Gräberfeld in Csengele - Szeged-Csengele-Fekete halom). Móra Ferenc Múzeum Évkönyve (Szeged), 43-62.

TRIFUNOVIĆ, STANKO

2000 Istraživački radovi i rasprave nasela limiganta i slovena u Banatu i Bačkoj. Glasnik Srpsko arheološko

TRUGLY SÁNDOR društvo (Beograd) 15-16, 1999-2000.

1996 A komáromi avar telep (Die awarische Siedlung von Komárom/Komárno). Communicationes VADAY ANDREA Archaeologicae Hungariae (Budapest) 125-150.

1999 Az avar kori telep. In: Petercsák T.-Szabó J. J. (szerk.): Kompolt-Kistér. Újkőkori, bronzkori, szarmata és avar lelőhely. Leletmentő ásatás az M3-as autópálya nyomvonalán (A Neolithic, Bronze Age, Sarmatian and Avar site rescue excavation at the M3 motorway). Eger, 233-253. 
VIDA TIVADAR

1991a Újabb adatok az avar kori „fekete kerámia” és a korongolatlan cserépbográcsok kérdéséhez (Weitere Angaben zur Frage der awarenzeitlichen "schwarzen Keramik“ und der handgeformten Tonkessel). Móra Ferenc Múzeum Évkönyve (Szeged) 1984/1985-2, 385-400.

1991b Chronologie und Verbreitung einiger awarenzeitlicher Keramiktypen. Antaeus Communicationes ex Instituto Archaeologico Scientiarum Hungaricae (Budapest) 19-20, 131-144.

1996 Avar period settlement remains and graves at the site of Gyoma 133. In: Bökönyi S. (ed.): Cultural and Landscape Changes in South-East Hungary II. Prehistoric, Roman Barbarian and Late Avar Settlement at Gyoma 133 (Békés County Microregion). Archaeolingua 5. Budapest, 323-364.

1999 Die awarenzeitliche Keramik I (6.-7. Jh.). Varia Archaeologica Hungarica 8. Budapest.

2009 „... Kérték, hogy Pannóniában lakhassanak”. Az avarok letelepedése. In: Anders A.-Szabó M.-Raczky P. (szerk.): Régészeti dimenziók. Tanulmányok az ELTE BTK Régészettudományi Intézetének tudományos múhelyéból. Budapest, 105-123.

2011 Sütőharangok és sütőfedők. Régészeti adatok Dél- és Közép-Európa étkezési kultúrájához. In: Kolozsi B.-Szilágyi K. A. (szerk.): Sötét idők falvai. 8-11. századi települések a Kárpát-medencében. Debrecen, 701-817.

WILHELM GÁBOR

2010 Késő avar kori településrészlet és temetkezés Kiskundorozsma határában (Spätawarenzeitliches Siedlungsfragment und Bestattung in der Gemarkung von Kiskundorozsma). In: Lőrinczy G. (szerk.): Pusztaszertől Algyőig. Régészeti lelóhelyek és leletek egy gázvezeték nyomvonalának Csongrád megyei szakaszán. Móra Ferenc Múzeum Évkönyve - Monumenta Archaeologica (Szeged) 2, 211-229.

ZÁBOJNÍK, JOZEF

1988 On the problems of settlements of the Avar Khaganate period in Slovakia (K problematike sídlisk z obdobia avarského kaganátu na Slovensku). Archeologické rozhledy (Praha) 40, 401-437, 480.

\section{AWARENZEITLICHER SIEDLUNGSTEIL VON CSANÁDPALOTA-ORSZÁGHATÁR DIE FRAGE DER IDENTIFIKATION DER SIEDLUNGEN DES 7. JAHRHUNDERTS IN DER TIEFEBENE}

\section{DÁNIEL PÓPITY}

Der Artikel beschreibt einen neuerlich entdeckten awarenzeitlichen Siedlungsteil neben Csanádpalota bzw. beschäftigt sich mit der Identifikation der Siedlungen des 7. Jahrhunderts. Während dieser Siedlungshorizont in Transdanubien schon umgeschrieben worden war, fehlen bisher die Aufnahme und die Umschreibung der Fundorte in der Tiefebene. Der Verfasser analysiert diesen frühen Siedlungshorizont auf Grund der erreichbaren topographischen und besonders der authentischen Ausgrabungsdaten. Der Vergleich und die Auswertung der Daten machen auf das Problem der Datierung der einzelnen Keramiktypen aufmerksam. Für die Identifizierung der früh- und mittelawarenzeitlichen Sied- lungen sind unter den aus Siedlungsobjekten stammenden Gegenständen diejenige von Bedeutung, die nicht aus Keramik, sondern aus Metall oder Knochen gemacht worden sind. Der Fundort Csanádpalota-Staatsgrenze ist in dieser Hinsicht sehr wichtig, da es hier auch ein Gürtelbeschlag vom Typ Tarnaméra ans Licht gekommen ist. Durch diesen Fundort - ähnlich wie durch den awarenzeitlichen Siedlungsteil von Hajdúnánás-Verestengerjárás, der früher schon publiziert wurde - nimmt die Zahl der awarischen Siedlungen des 7. Jahrhunderts zu, wenn wir den Datierungswert der in den Siedlungen gefundenen Metallgegenstände akzeptieren. 